Review

\title{
Diversity of vertebrate nicotinic acetylcholine receptors
}

\author{
Neil S. Millar ${ }^{\mathrm{a}, *}$, Cecilia Gotti ${ }^{\mathrm{b}}$ \\ ${ }^{a}$ Department of Neuroscience, Physiology and Pharmacology, University College London, London WC1E 6BT, UK \\ ${ }^{\mathrm{b}}$ CNR, Institute of Neuroscience, Cellular and Molecular Pharmacology, Department of Medical Pharmacology, University of Milan, Milan, Italy
}

\section{A R T I C L E I N F O}

Article history:

Received 28 May 2008

Received in revised form 14 July 2008

Accepted 15 July 2008

\section{Keywords:}

Acetylcholine receptor

Nicotinic receptor

Receptor diversity

\begin{abstract}
A B S T R A C T
Nicotinic acetylcholine receptors (nAChRs) are pentameric neurotransmitter receptors. They are members of the Cys-loop family of ligand-gated ion channels which also include ionotropic receptors for 5-hydroxytryptamine (5-HT), $\gamma$-aminobutyric acid (GABA) and glycine. Nicotinic receptors are expressed in both the nervous system and at the neuromuscular junction and have been implicated in several neurological and neuromuscular disorders. In vertebrates, seventeen nAChR subunits have been identified ( $\alpha 1-\alpha 10, \beta 1-\beta 4, \gamma, \delta$ and $\varepsilon$ ) which can co-assemble to generate a diverse family of nAChR subtypes. This review will focus on vertebrate nAChRs and will provide an overview of the extent of nAChR diversity based on studies of both native and recombinant nAChRs.
\end{abstract}

(C) 2008 Elsevier Ltd. All rights reserved.

\section{Introduction}

Nicotinic acetylcholine receptors (nAChRs) are excitatory neurotransmitter receptors and members of the super-family of ligand-gated ion channels (Changeux and Edelstein, 2005). They are complex pentameric transmembrane proteins assembled from a diverse collection of subunits. In this review, which will examine the extent of nAChR diversity, we will focus on vertebrate nAChRs, with particular emphasis on studies conducted with mammalian receptors. Although, nAChRs are expressed in both vertebrate and invertebrate species a discussion of invertebrate nAChRs is beyond the scope of this review. The diversity of nAChRs in invertebrate species has, however, been discussed in detail elsewhere (Jones et al., 2007; Millar and Denholm, 2007).

\section{Nicotinic receptor structure}

Recent structural studies have provided an insight into the three dimensional structure of nAChRs. In particular, a high resolution structure $(4 \AA$ ) of the nAChR from the marine ray Torpedo (Unwin, 2005) has revealed important information about $n A C h R$ structure and has been invaluable in the interpretation of functional and pharmacological data (Fig. 1). In addition, higher resolution structural information has become available from studies of proteins which show close sequence similarity to nAChRs. These include a cytoplasmic acetylcholine binding protein (AChBP) from the pond snail Lymnaea (Brejc et al., 2001; Smit et al., 2001) and prokaryotic ligand-gated ion channels (Bocquet et al., 2007; Hilf and Dutzler, 2008). An atomic resolution structure of the AChBP from Lymnaea

\footnotetext{
* Corresponding author. Tel.: +44 (0) 207679 7241; fax: +44 (0) 2076797245 . E-mail address: n.millar@ucl.ac.uk (N.S. Millar).
}

has been obtained by X-ray crystallography (Brejc et al., 2001) and has been used extensively as a model for the nAChR extracellular domain. In addition, the structure of a pentameric transmembrane ligand-gated ion channel from the bacterium Erwinia chrysanthemi has been determined by X-ray crystallography (Hilf and Dutzler, 2008) and has provided further insights into the structure of the super-family of ligand-gated ion channels. However, until recently, no atomic resolution structural information has been available for any $\mathrm{nAChR}$. This situation has recently been rectified by the determination of an atomic resolution (1.94 $\AA$ ) structure of the extracellular domain of the nAChR $\alpha 1$ subunit (Fig. 1 ) by X-ray crystallography (Dellisanti et al., 2007). Such information will, undoubtedly, be of considerable benefit to our understanding of these complex neurotransmitter receptors.

\section{Subunit nomenclature}

The nomenclature of $n A C h R$ subunits has arisen in a somewhat arbitrary manner. Early biochemical studies of nAChRs purified from the electric organ of fish such as the marine ray Torpedo and the freshwater eel Electrophorus identified four protein subunits (for a detailed review, see Popot and Changeux, 1984). The four subunits were assigned the Greek letters $\alpha, \beta, \gamma$ and $\delta$ on the basis of their increasing apparent molecular weights when resolved on polyacrylamide gels. Of these four subunits, only the $\alpha$ subunit could be labelled by quaternary ammonium affinity-labelling reagents, which led to the conclusion that the $\alpha$ subunit was the principal agonist binding site (Weill et al., 1974). The subsequent molecular cloning of the Torpedo $\alpha$ subunit (Noda et al., 1982; Sumikawa et al., 1982) identified two adjacent cysteine residues (Cys192 and Cys193), which were believed to be important in agonist binding. The convention which has been adopted 
A

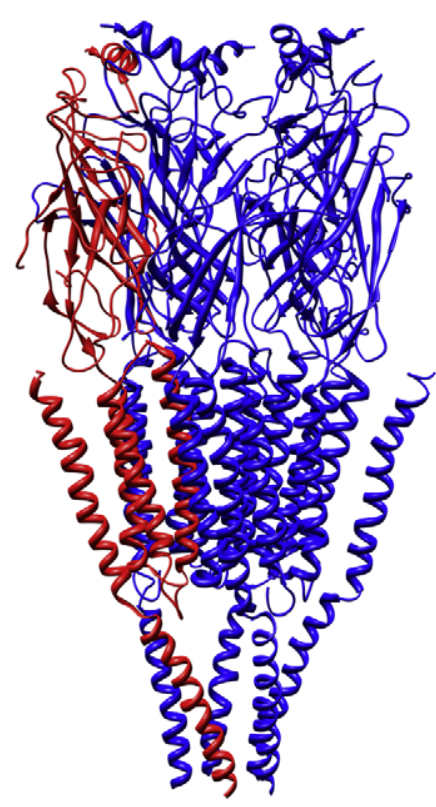

B

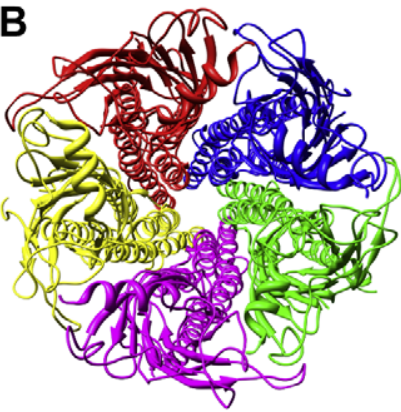

C

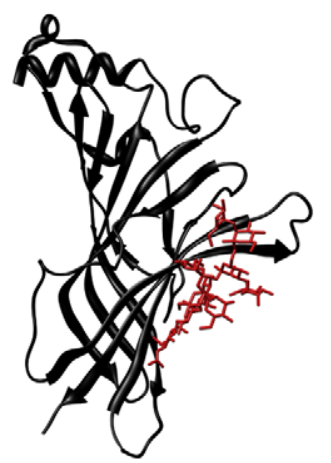

Fig. 1. Three dimensional structure of the Torpedo $n A C h R$. The structure of the $n A C h R$ expressed in the electric organ of the marine ray Torpedo has been determined at $4 \AA$ resolution (Unwin, 2005) and has been used extensively a model for other nAChRs. Representations of the Torpedo nAChR (as ribbon structures, representing only backbone amino acids) are shown viewed from the side (A) and from above (B). In the side view (A), one of the five subunits has been shaded a different colour (red) for clarity. In the top view (B) all five subunits have been shaded in different colours to indicate more clearly the boundaries between subunits. (C) The atomic resolution (1.94 $\AA$ ) structure of the mouse $\mathrm{nAChR} \alpha 1$ subunit, determined by X-ray diffraction (Dellisanti et al., 2007), is illustrated. Carbohydrates, linked to Asn141, are illustrated as a stick model in red.

subsequently for the nomenclature of nAChR subunits is that nAChRs which contain two cysteine residues at positions analogous to Cys192 and Cys193 in the Torpedo $\alpha$ subunit have been classified as $\alpha$-type subunits. Non- $\alpha$ subunits expressed at the vertebrate neuromuscular junction have been assigned the names $\beta 1, \gamma, \delta$ and $\varepsilon$, whereas non- $\alpha$ subunits expressed in the vertebrate nervous system have been assigned the names $\beta 2-\beta 4$. Nicotinic receptors expressed in either muscle cells and or within the nervous system are commonly referred to as 'muscle-type' and 'neuronal' nAChRs, although it has been suggested that such terms should not become a formal part of nAChR nomenclature or classification (Lukas et al., 1999). The term 'neuronal', for example, is used widely to describe the $\alpha 2-\alpha 10$ and $\beta 2-\beta 4$ subunits, despite evidence that some of these subunits are expressed in non-neuronal locations (Sharma and Vijayaraghavan, 2002).

On the basis of affinity-labelling experiments (Weill et al., 1974), it was assumed that $\alpha$ subunits are agonist binding subunits, whereas non- $\alpha$ subunits are 'structural' subunits. However, more recent studies indicate that nicotinic agonists bind at subunit interfaces (reviewed by Sine, 2002) and that both $\alpha$ and non$\alpha$ subunits are able to contribute to the nicotinic agonist binding site (Luetje and Patrick, 1991). A consequence of this is that the terms 'agonist-binding' and 'structural' may be less appropriate descriptions of the roles performed by nAChR subunits. What may be more useful is a terminology which distinguishes between subunits which form what has been referred to extensively as the 'principal' and 'complementary' subunit interface of the agonist binding site (Bertrand and Changeux, 1995; Corringer et al., 1995, 2000; Arias, 1997).

The system of nAChR subunit nomenclature, which is based upon the assignment of Greek letters, has led to some anomalies. As a consequence, the designation " $\alpha$ " and " $\beta$ " subunit cannot necessarily be taken to imply functional equivalence of subunits. Whereas all heteromeric nAChRs contain at least one $\alpha$-type subunit which can act as the principal subunit at the agonist binding site, not all $\alpha$ subunits can perform this role. The $\alpha 5$ and $\alpha 10$ subunits, for example, are only able to form functional nAChRs when co-assembled with another $\alpha$ subunit. In fact, the $\alpha 5$ subunit has greater sequence similarity to $\beta 3$ than it does to other nAChR $\alpha$ or $\beta$ subunits (Boulter et al., 1990). It has been suggested that the presence or absence of Tyr190 (rather than Cys192 and Cys193) might be a better basis for the classification of nAChR subunits (Abramson and Taylor, 1990), since this would place the $\alpha 5$ subunit in a group with other 'non- $\alpha$ ' subunits. The problem of using methods such as these to classify nAChR subunits is illustrated by the fact that the recently identified $\alpha 10$ subunit would still be classified as an $\alpha$-type subunit (using either of these two systems), despite its apparent inability to act as a principal subunit at the agonist binding site (Elgoyhen et al., 2001; Baker et al., 2004). Unfortunately, even greater anomalies concerning the use of Greek letters for $\mathrm{nAChR}$ subunit nomenclature have arisen for invertebrate species, as has been discussed elsewhere (Millar, 2003; Millar and Denholm, 2007).

Another long established convention is that nAChR subtypes are referred to by their subunit composition. For example, $\alpha 4 \beta 2$ refers to a nAChR subtype containing only $\alpha 4$ and $\beta 2$ subunits (even though the precise subunit stoichiometry of subunits within the receptor may not be known). Also, by convention, when the precise subunit composition of a nAChR subtype is unknown, this uncertainty is indicated by an asterisk (Lukas et al., 1999; Luetje, 2004). For example, $\alpha 4 \beta 2^{*}$ indicates a nAChR which is known to contain $\alpha 4$ and $\beta 2$ subunits but which may also contain additional subunit subtypes. In situations where both the subunit composition and also the subunit stoichiometry are known, the number of each subunit present in the assembled pentamer is indicated by subscript numbers (for example $(\alpha 1)_{2} \beta 1 \gamma \delta$ ). Several authors have used subscript numbers for nAChR subunit nomenclature but this has been discouraged (Lukas et al., 1999), in part, because of the potential confusion that this can cause with the use of subscript numbers to designate subunit stoichiometry.

\section{Subunit diversity}

Seventeen $\mathrm{nAChR}$ subunits have been identified in vertebrate species $(\alpha 1-\alpha 10, \beta 1-\beta 4, \gamma, \delta$ and $\varepsilon)$. All of these subunits, with the exception of $\alpha 8$ (which has been identified only in avian species), are found in humans and in other mammalian species. As will be discussed below, although some nAChR subunits such as $\alpha 7$ are able to generate functional homomeric receptors (containing five copies of a single subunit), most $\mathrm{nAChR}$ subunits form functional receptors only when co-assembled with other subunits to generate heteromeric receptors. Clearly, there are many possible combinations in which the sixteen mammalian nAChR subunits could potentially co-assemble. It appears, however, that assembly of nAChRs, like that of other oligomeric ion channels, is a tightly regulated and ordered process, which requires appropriate subunit-subunit interactions (reviewed by Green and Millar (1995) and Millar and Harkness (2008)). Although the potential exists for the formation of nAChRs with very many different subunit combinations, it appears that native nAChRs are assembled into functional pentamers of relatively restricted number of subunit combinations, whilst still generating considerable nAChR diversity (Table 2).

\section{Subunit stoichiometry}

As was mentioned above, some nAChR subunits (such as $\alpha 7$ ) are able to generate functional homomeric receptors (Couturier et al., 
1990). In contrast, most nAChRs subtypes are heteromeric receptors, containing at least one type of $\alpha$ subunit and one type of non$\alpha$ subunit. The subunit stoichiometry of heteromeric nAChRs has been the subject of considerable research. For some nAChRs, such as the muscle-type nAChR, subunit stoichiometry has been revealed directly by high resolution structural information (Unwin, 2005). Like the Torpedo electric organ nAChR, receptors expressed at the adult mammalian neuromuscular junction appear to have a fixed subunit stoichiometry of $(\alpha 1)_{2} \beta 1 \delta \varepsilon$, in which two copies of the $\alpha 1$ subunit co-assemble with a single copies of the $\beta, \delta$ and $\varepsilon$ subunits. In embryonic muscle, nAChRs contain a $\gamma$ rather than an $\varepsilon$ subunit, giving a subunit stoichiometry of $(\alpha 1)_{2} \beta 1 \gamma \delta$. Muscle nAChRs have two non-equivalent agonist binding sites at the $\alpha-$ $\delta$ and $\alpha-\gamma / \varepsilon$ subunit interfaces (Neubig and Cohen, 1979; Sine, 1993), whereas the $\beta 1$ subunit does not participate directly in the formation of an agonist binding site.

Whist the subunit stoichiometry of other heteromeric nAChRs is less clearly defined, there is evidence that at least some heteromeric neuronal nAChRs co-assemble with two $\alpha$ subunits and three non- $\alpha(\beta)$ subunits. For example, heterologous expression studies performed with reporter mutations suggest that $\alpha 4 \beta 2$ and $\alpha 3 \beta 4$ nAChRs both contain two $\alpha$ subunits co-assembled with three $\beta$ subunits (Cooper et al., 1991; Boorman et al., 2000) a conclusion which is also supported by more direct biochemical studies (Anand et al., 1991). However, more recent data indicate that this is an oversimplification. There is now strong evidence to indicate that some neuronal $\mathrm{nAChR}$ can assemble into nAChRs with alternate stoichiometries and that this can influence pharmacological and functional properties (Zwart and Vijverberg, 1998; Nelson et al., 2003). There is evidence, for example, that $\alpha 4 \beta 2$ nAChRs can assemble in two different stoichiometries $\left((\alpha 4)_{2}(\beta 2)_{3}\right.$ and $\left.(\alpha 4)_{3}(\beta 2)_{2}\right)$ which differ in properties such as agonist and antagonist sensitivity (Zwart and Vijverberg, 1998; Nelson et al., 2003; Moroni et al., 2006) and calcium permeability (Tapia et al., 2007). Recent studies are also providing an insight into the subunit stoichiometry of more complex neuronal heteromeric nAChRs. The use of reporter mutations has provided evidence that nAChRs containing the $\alpha 3, \beta 3$ and $\beta 4$ subunits assemble with a stoichiometry of $(\alpha 3)_{2} \beta 3(\beta 4)_{2}$ (Boorman et al., 2000). Another potentially powerful approach to examining receptor stoichiometry has come from studies of artificially linked subunits (Zhou et al., 2003; GrootKormelink et al., 2004, 2006), although there are several problems which can arise with such approaches (Groot-Kormelink et al., 2004; Ericksen and Boileau, 2007).

\section{Receptor diversity revealed by studies of recombinant nAChRs}

The five muscle-type nAChRs ( $\alpha 1, \beta 1, \gamma, \delta$ and $\varepsilon$ ) co-assemble efficiently in heterologous expression systems into two distinct receptor subtypes $\left((\alpha 1)_{2} \beta 1 \gamma \delta\right.$ and $\left.(\alpha 1)_{2} \beta 1 \delta \varepsilon\right)$, an observation which, as is discussed below, is in agreement with studies of native nAChRs expressed in embryonic and adult muscle, respectively. There have been reports of functional recombinant $\mathrm{nAChRs}$ with fewer than four different muscle-type nAChR subunits (see Table 1), but these appear to be formed less efficiently than the fully assembled receptors (Charnet et al., 1992; Liu and Brehm, 1993) and have not been detected as native nAChRs (Table 2 ).

The $\alpha 7$ and $\alpha 8$ subunits are the only two vertebrate nAChR subunits (and $\alpha 7$ is the only mammalian subunit) which appear to preferentially form homomeric, rather than heteromeric, receptors in heterologous expression systems (Couturier et al., 1990; Gerzanich et al., 1994; Gotti et al., 1994). This is consistent with evidence that these subunits form homomeric nAChRs in native systems (Keyser et al., 1993; Chen and Patrick, 1997; Drisdel and Green, 2000). Whilst the $\alpha 7$ and $\alpha 8$ subunits both readily form functional
Table 1

Subunit combinations identified from studies with recombinant nAChRs

\begin{tabular}{|c|c|c|}
\hline nAChR subtype & & Selected references \\
\hline Homomeric & $\begin{array}{l}\alpha 7 \\
\alpha 8 \\
\alpha 9^{\mathrm{a}}\end{array}$ & $\begin{array}{l}\text { Couturier et al. (1990) } \\
\text { Gerzanich et al. (1994), Gotti et al. (1994) } \\
\text { Elgoyhen et al. (1994) }\end{array}$ \\
\hline $\begin{array}{l}\text { Heteromeric } \\
\quad \text { (pair) }\end{array}$ & $\begin{array}{l}\alpha 1 \gamma^{\mathrm{a}} \\
\alpha 1 \delta^{\mathrm{a}} \\
\alpha 2 \beta 2 \\
\alpha 2 \beta 4 \\
\alpha 3 \beta 2 \\
\alpha 3 \beta 4 \\
\alpha 4 \beta 2 \\
\alpha 4 \beta 4 \\
\alpha 6 \beta 2 \\
\alpha 6 \beta 4 \\
\alpha 7 \beta 2 \\
\alpha 9 \alpha 10\end{array}$ & $\begin{array}{l}\text { Liu and Brehm (1993) } \\
\text { Liu and Brehm (1993) } \\
\text { Papke et al. (1989) } \\
\text { Duvoisin et al. (1989) } \\
\text { Papke et al. (1989) } \\
\text { Duvoisin et al. (1989) } \\
\text { Papke et al. (1989) } \\
\text { Duvoisin et al. (1989) } \\
\text { Fucile et al. (1998) } \\
\text { Gerzanich et al. (1997) } \\
\text { Khiroug et al. (2002) } \\
\text { Elgoyhen et al. (2001), Sgard et al. (2002) }\end{array}$ \\
\hline $\begin{array}{l}\text { Heteromeric } \\
\quad \text { (triplet) }\end{array}$ & $\begin{array}{l}\alpha 1 \beta 1 \gamma^{\mathrm{a}} \\
\alpha 1 \beta 1 \delta^{\mathrm{a}} \\
\alpha 1 \gamma \delta^{\mathrm{a}} \\
\alpha 1 \delta \varepsilon^{\mathrm{a}} \\
\alpha 3 \alpha 5 \beta 2 \\
\alpha 3 \alpha 5 \beta 4 \\
\alpha 3 \alpha 6 \beta 2 \\
\alpha 3 \alpha 6 \beta 4 \\
\alpha 3 \beta 3 \beta 4 \\
\alpha 4 \alpha 5 \beta 2 \\
\alpha 4 \beta 2 \beta 3 \\
\alpha 5 \alpha 6 \beta 2 \\
\alpha 5 \alpha 7 \beta 2 \\
\alpha 5 \alpha 7 \beta 4 \\
\alpha 6 \beta 2 \beta 3 \\
\alpha 6 \beta 3 \beta 4\end{array}$ & $\begin{array}{l}\text { Kullberg et al. (1990), Liu and Brehm (1993) } \\
\text { Charnet et al. (1992), Liu and Brehm (1993) } \\
\text { Liu and Brehm (1993) } \\
\text { Liu and Brehm (1993) } \\
\text { Wang et al. (1996), Gerzanich et al. (1998) } \\
\text { Wang et al. (1996), Fucile et al. (1997) } \\
\text { Kuryatov et al. (2000) } \\
\text { Fucile et al. (1998), Kuryatov et al. (2000) } \\
\text { Groot-Kormelink et al. (1998) } \\
\text { Ramirez-Latorre et al. (1996), Girod et al. (1999) } \\
\text { Kuryatov et al. (2008) } \\
\text { Kuryatov et al. (2000) } \\
\text { Crabtree et al. (1997), Girod et al. (1999) } \\
\text { Crabtree et al. (1997) } \\
\text { Tumkosit et al. (2006) } \\
\text { Kuryatov et al. (2000), Tumkosit et al. (2006) }\end{array}$ \\
\hline $\begin{array}{l}\text { Heteromeric } \\
\text { (quadruplet) }\end{array}$ & $\begin{array}{l}\alpha 1 \beta 1 \gamma \delta \\
\alpha 1 \beta 1 \delta \varepsilon\end{array}$ & $\begin{array}{l}\text { Mishina et al. (1986) } \\
\text { Mishina et al. (1986) }\end{array}$ \\
\hline
\end{tabular}

a These subunit combinations generate functional recombinant nAChRs relatively inefficiently and appear not to be combinations expressed as native nAChRs (see Table 2). Due to constraints of space, only a limited number of references have been included in the table. See main text for additional references. The $\beta 3$ subunit is able to co-assemble with several other nAChR subunits, including $\alpha 7$, but in most cases it has a strong dominant-negative effect (Palma et al., 1999; Broadbent et al., 2006). Such subunit combinations have not been included in the table.

homomeric nAChRs when expressed in Xenopus oocytes, they do so very much less efficiently in many types of cultured cell lines (Cooper and Millar, 1997, 1998; Kassner and Berg, 1997; Rangwala et al., 1997). Recent studies have revealed that co-expression of either $\alpha 7$ or $\alpha 8$ with a nAChR-selective molecular chaperone RIC-3 can facilitate the formation of functional homomeric nAChRs in otherwise non-permissive cell types (Castillo et al., 2005; Lansdell et al., 2005, 2008; Williams et al., 2005). RIC-3 is an ER-resident protein, with most studies indicating that it does not remain associated with assembled nAChRs on the cell surface (reviewed by Millar, 2008). In addition to the evidence that $\alpha 7$ can form a homomeric $\mathrm{nAChR}$, there is evidence from heterologous expression studies that it can co-assemble with $\beta 2$ to form a functional heteromeric receptor (Khiroug et al., 2002). There have also been reports of the co-assembly of $\alpha 7$ with $\beta 3$, but this appears to lead to the formation of a non-functional receptor (Palma et al., 1999; Broadbent et al., 2006).

The nAChR $\alpha 9$ subunit, which is expressed predominantly in hair cells of the cochlear, can generate homomeric nAChRs when expressed in Xenopus oocytes (Elgoyhen et al., 1994), but it forms a functional nAChR very much more efficiently when it is coexpressed with the $\alpha 10$ subunit (Elgoyhen et al., 2001; Sgard et al., 2002). As is discussed below, this finding is consistent with evidence which indicates that native $\alpha 9$-containing nAChRs are heteromeric complexes with $\alpha 10$ (Elgoyhen et al., 2001; Katz et al., 2004; Vetter et al., 2007). Furthermore, there is evidence from 
Table 2

Subunit combinations identified from studies with native vertebrate AChRs

\begin{tabular}{|c|c|c|c|}
\hline Subtype & Species & Localization & References \\
\hline$\overline{\alpha 1 \beta 1 \gamma \delta}$ & B & Muscle & Nelson et al. (1992) \\
\hline$\alpha 1 \beta 1 \delta \varepsilon$ & B & Muscle & Nelson et al. (1992) \\
\hline \multirow[t]{3}{*}{$\alpha 2 \alpha 4 \beta 2^{*}$} & $\mathrm{C}$ & Retina & Vailati et al. (2003) \\
\hline & $\mathrm{R}$ & Retina & Moretti et al. (2004), Marritt et al. (2005) \\
\hline & M & Cortex & Quik et al. (2005) \\
\hline$\alpha 2 \alpha 5 \beta 2$ & $\mathrm{C}$ & Optic lobe & Balestra et al. (2000) \\
\hline \multirow[t]{3}{*}{$\alpha 2 \beta 2^{*}$} & $\mathrm{C}$ & Retina & Vailati et al. (2003) \\
\hline & $\mathrm{R}$ & Retina & Moretti et al. (2004), Marritt et al. (2005) \\
\hline & & Interpeduncular nucleus & Gotti et al. (2006b) \\
\hline \multirow[t]{2}{*}{$\alpha 2 \beta 4^{*}$} & $\mathrm{C}$ & Retina & Vailati et al. (2003) \\
\hline & $\mathrm{R}$ & Retina & Moretti et al. (2004), Marritt et al. (2005) \\
\hline$\alpha 3 \alpha 4 \beta 2^{*}$ & M & Cortex & Quik et al. (2005) \\
\hline$\alpha 3 \alpha 4 \alpha 6 \beta 2^{*}$ & $\mathrm{R}$ & Optic nerve & Cox et al. (2008) \\
\hline \multirow[t]{2}{*}{$\alpha 3 \alpha 5 \beta 2^{*}$} & $\mathrm{R}$ & Superior colliculus & Gotti et al. (2005b) \\
\hline & $\mathrm{H}$ & SH-SY5Y cells & Wang et al. (1996) \\
\hline$\alpha 3 \alpha 5 \beta 2 \beta 4$ & $\mathrm{C}$ & Ciliary ganglia & Conroy and Berg (1998) \\
\hline \multirow[t]{3}{*}{$\alpha 3 \alpha 5 \beta 4^{*}$} & $\mathrm{C}$ & Ciliary ganglia & Vernallis et al. (1993) \\
\hline & $\mathrm{R}$ & Superior cervical ganglia & Del Signore et al. (2002), Mao et al. (2006) \\
\hline & $\mathrm{R}$ & Cerebellum & Turner and Kellar (2005) \\
\hline \multirow[t]{2}{*}{$\alpha 3 \alpha 6 \beta 2^{*}$} & $\mathrm{C}$ & Retina, & Vailati et al. (1999) \\
\hline & $\mathrm{R}$ & Retina, optic nerve & Moretti et al. (2004), Cox et al. (2008) \\
\hline \multirow[t]{2}{*}{$\alpha 3 \beta 2^{*}$} & $\mathrm{R}$ & Retina, optic nerve & Moretti et al. (2004), Cox et al. (2008) \\
\hline & M & Striatum & Quik et al. (2005) \\
\hline$\alpha 3 \beta 2 \beta 3^{*}$ & $\mathrm{R}$ & Superior colliculus & Gotti et al. (2005b) \\
\hline \multirow[t]{2}{*}{$\alpha 3 \beta 2 \beta 4^{*}$} & $\mathrm{R}$ & Retina, cerebellum & Marritt et al. (2005), Turner and Kellar (2005) \\
\hline & $\mathrm{R}$ & Superior cervical ganglia & Mao et al. (2006) \\
\hline$\alpha 3 \beta 3 \beta 4$ & $\mathrm{R}$ & Habenula, interpeduncular nucleus & Gotti et al. (2006b) \\
\hline$\alpha 3 \beta 4$ & $\mathrm{R}$ & Pineal gland, cerebellum & Hernandez et al. (2004), Turner and Kellar (2005) \\
\hline$\alpha 3 \beta 4^{\circ}$ & $\mathrm{R}$ & Medial habenula & Quick et al. (1999) \\
\hline \multirow[t]{3}{*}{$\alpha 4 \alpha 5 \beta 2$} & $\mathrm{C}$ & Brain & Conroy and Berg (1998) \\
\hline & $\mathrm{R}$ & Striatum, SC, LGN & Zoli et al. (2002) \\
\hline & $\mathrm{R}$ & Other brain areas & Brown et al. (2007) \\
\hline \multirow[t]{3}{*}{$\alpha 4 \alpha 6 \beta 2 \beta 3$} & $\mathrm{R}$ & Retina, striatum & Zoli et al. (2002), Moretti et al. (2004) \\
\hline & $\mathrm{R}$ & SC, LGN, optic nerve & Gotti et al. (2005b), Cox et al. (2008) \\
\hline & M & Striatum & Quik et al. (2005) \\
\hline \multirow[t]{3}{*}{$\alpha 4 \beta 2$} & $\mathrm{C}$ & Brain & Whiting and Lindstrom (1986) \\
\hline & $\mathrm{R}$ & Brain & Whiting et al. (1987) \\
\hline & B & Brain & Whiting and Lindstrom (1988) \\
\hline$\alpha 4 \beta 2^{*} \circ$ & $\mathrm{R}$ & Spinal cord & Marubio et al. (1999) \\
\hline$\alpha 4 \beta 4$ & $\mathrm{C}$ & Retina & Barabino et al. (2001) \\
\hline$\alpha 4 \beta 4^{*}$ & $\mathrm{R}$ & Retina & Moretti et al. (2004) \\
\hline$\alpha 6 \beta 2^{*}$ & $\mathrm{R}$ & Retina & Moretti et al. (2004) \\
\hline$\alpha 6 \beta 2^{\circ}$ & $\mathrm{R}$ & Striatum & Salminen et al. (2007) \\
\hline \multirow[t]{3}{*}{$\alpha 6 \beta 2 \beta 3$} & $\mathrm{R}$ & Striatum, & Zoli et al. (2002) \\
\hline & & Retina, SC, LGN & Moretti et al. (2004), Gotti et al. (2005a) \\
\hline & M & Striatum & Quik et al. (2005) \\
\hline \multirow[t]{2}{*}{$\alpha 6 \beta 2 \beta 3^{*}$} & $\mathrm{C}$ & Retina & Vailati et al. (1999) \\
\hline & $\mathrm{H}$ & Striatum & Gotti et al. (2006a) \\
\hline$\alpha 6 \beta 3 \beta 4^{*}$ & $\mathrm{C}$ & Retina & Vailati et al. (1999) \\
\hline$\alpha 6 \beta 4^{*}$ & $\mathrm{C}$ & Retina & Vailati et al. (1999) \\
\hline \multirow[t]{3}{*}{$\alpha 7$} & $\mathrm{C}$ & Retina, optic lobe & Anand et al. (1993), Gotti et al. (1997) \\
\hline & $\mathrm{R}$ & Brain & Drisdel and Green (2000) \\
\hline & $\mathrm{H}$ & IMR-32 cells & Gotti et al. (1995) \\
\hline$\alpha 7 \alpha 8$ & $\mathrm{C}$ & Retina, optic lobe & Anand et al. (1993), Keyser et al. (1993) \\
\hline$\alpha 8$ & $\mathrm{C}$ & Retina & Anand et al. (1993), Gotti et al. (1997) \\
\hline$\alpha 9 \alpha 10^{\circ}$ & $\mathrm{R}$ & Cochlea & Elgoyhen et al. (2001), Katz et al. (2004) \\
\hline
\end{tabular}

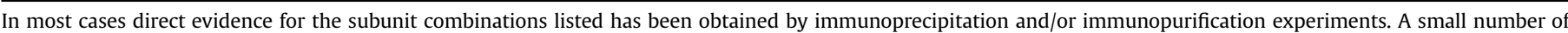

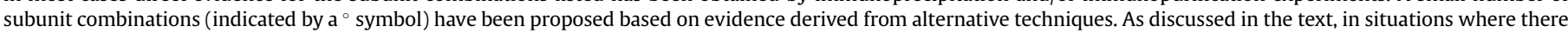

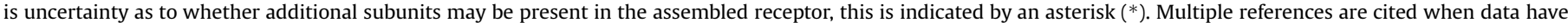

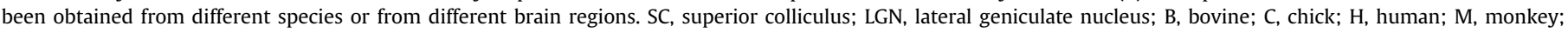
$\mathrm{R}$, rodent.

studies conducted in Xenopus oocytes that $\alpha 9$ and $\alpha 10$ co-assemble with the stoichiometry $(\alpha 9)_{2}(\alpha 10)_{3}$ (Plazas et al., 2005).

The neuronal $\alpha 2-\alpha 6$ and $\beta 2-\beta 4$ subunits fail to generate functional nAChRs when expressed individually in artificial expression systems such as the Xenopus oocyte (Boulter et al., 1987; Duvoisin et al., 1989; Luetje and Patrick, 1991), findings which are consistent with studies performed in cultured cell lines (Rogers et al., 1991; Whiting et al., 1991; Wong et al., 1995; Ragozzino et al., 1997). Heterologous expression studies have also demonstrated that, when these subunits are expressed alone, they are largely retained within the cell rather than being expressed on the cell surface (Cooper et al., 1999; Harkness and Millar, 2002). Despite their inability to form homomeric nAChRs, a subset of these subunits (notably $\alpha 2-\alpha 4, \beta 2$ and $\beta 4$ ) are able to form functional nAChRs when expressed as pair-wise combinations of one $\alpha$ and one $\beta$ subunit (Duvoisin et al., 1989; Papke et al., 1989). Functional expression has been observed for pair-wise subunit combinations such as $\alpha 2 \beta 4, \alpha 3 \beta 2, \alpha 3 \beta 4, \alpha 4 \beta 2$ and $\alpha 4 \beta 4$ (Duvoisin et al., 1989; Papke et al., 1989). It appears that the $\alpha 5$ and $\beta 3$ subunits (which, as discussed earlier, show greater sequence similarity to one another 
than to other nAChR subunits) are unable to generate functional nAChRs unless co-expressed as third subunits with another $\alpha$ and $\beta$ subunit pair. For some time the $\alpha 6$ subunit appeared to be similar in this respect to $\alpha 5$ and $\beta 3$ and, like the $\alpha 5$ and $\beta 3$ subunits, had been described as being an 'orphan' subunit (Gerzanich et al., 1997). There have, however, been reports that the $\alpha 6$ subunit can generate functional recombinant $n A C h R s$ in a pair-wise combination either $\beta 2$ or $\beta 4$ (Gerzanich et al., 1997; Fucile et al., 1998), although the $\alpha 6 \beta 2$ subunit combination appears to be difficult to express in heterologous systems (Kuryatov et al., 2000).

Several heteromeric 'triplet' nAChR subunit combinations containing the $\alpha 5, \alpha 6$ or $\beta 3$ subunits have been identified by heterologous expression studies, primarily as a result of differences in electrophysiological properties when compared with pair-wise subunit combinations (Table 1 ). Several triplet subunit combinations containing $\alpha 5$ have been distinguished from heteromeric 'pair' subunit combinations on the basis of altered electrophysiological properties. These include: $\alpha 3 \alpha 5 \beta 2$ (Wang et al., 1996; Gerzanich et al., 1998), $\alpha 3 \alpha 5 \beta 4$ (Wang et al., 1996; Fucile et al., 1997; Gerzanich et al., 1998) and $\alpha 4 \alpha 5 \beta 2$ (Ramirez-Latorre et al., 1996). The $\beta 3$ subunit has been shown to co-assemble with several nAChR subunit combinations, but in almost all cases (i.e. other than $\alpha 3 \beta 3 \beta 4$ ) it appears to have a dominant-negative effect which results in a lack of functional expression of the $\beta 3$-containing assembled receptor complex (Palma et al., 1999; Broadbent et al., 2006). Co-assembly of $\beta 3$ into functional $\alpha 3 \beta 3 \beta 4 \mathrm{nAChRs}$ has, however, been demonstrated by heterologous expression in oocytes using a reporter mutation approach (Groot-Kormelink et al., 1998). Heterologous expression studies have also demonstrated the preferential co-assembly of $\alpha 6$ into triplet subunit combinations. These include $\alpha 6 \beta 3 \beta 4$ (Kuryatov et al., 2000; Tumkosit et al., 2006) and also $\alpha 3 \alpha 6 \beta 4$ and $\alpha 3 \alpha 6 \beta 2$ (Fucile et al., 1998; Kuryatov et al., 2000).

\section{Receptor diversity revealed by studies of native nAChRs}

As was discussed above, nAChRs expressed at the vertebrate neuromuscular junction display close structural similarity (in terms of subunit composition) to the well-characterised nAChR from the electric organ of Torpedo (as reviewed by Lindstrom et al. (1991) and Kalamida et al. (2007)). In contrast to the considerable subunit diversity amongst native nAChR subtypes which are expressed within the vertebrate nervous system (see below and Table 2), nAChRs expressed at the neuromuscular junction are a largely homogeneous population, although some receptor heterogeneity exists due to developmental changes in gene transcription. The $\mathrm{nAChR} \gamma$ subunit is expressed preferentially in embryonic muscle (and also in denervated adult muscle), whereas the $\varepsilon$ subunit is expressed preferentially in innervated adult muscle (Mishina et al., 1986; Witzemann et al., 1989). As a consequence of these transcriptional changes, nAChRs expressed in embryonic and in adult muscle have different subunit compositions, the stoichiometry of which is now well established $\left((\alpha 1)_{2} \beta 1 \gamma \delta\right.$ and $(\alpha 1)_{2} \beta 1 \delta \varepsilon$, in embryonic and adult muscle, respectively).

In contrast to the relatively homogeneous nature of nAChRs expressed at the neuromuscular junction, there is considerably greater diversity amongst $\mathrm{nAChRs}$ expressed throughout the central and peripheral nervous system (as summarised in Fig. 2 and Table 2). The fact that many neuronal cells express multiple nAChR subunits has hindered the identification and characterisation of native neuronal nAChRs. However, the increasing availability of knock-out or knock-in mice, subunit-specific antibodies and subtype-specific nicotinic ligands has made it possible to explore the diversity of subunit composition amongst neuronal nAChRs and examine the location of these subtypes within the nervous system. The picture which is emerging is one of considerable receptor diversity (see Fig. 2 and Table 2), but this information is starting to provide new insights into the role of nAChRs in normal and diseased brain (Paterson and Nordberg, 2000; Hogg et al., 2003; Gotti et al., 2006b). The important contribution which has been made by studies of knock-out and knock-in mice has been discussed in several recent reviews (Picciotto et al., 2001; Champtiaux and Changeux, 2002; Drago et al., 2003; Gotti and Clementi, 2004). These studies have, for example, helped to confirm earlier pioneering work which was preformed with nAChRs expressed in rat and chick brain (reviewed in Lindstrom (2000)) and which revealed that the $\alpha 4$ or $\beta 2$ subunits contribute to the high affinity nicotine binding sites in the brain (and are distinct from $\alpha$-bungarotoxinbinding nAChRs in the brain).

It is now well established that the most abundant nAChR subtypes in the nervous system are homomeric $\alpha 7$ receptors and heteromeric receptors containing only one type of $\alpha$ and one type of $\beta$ subunit. Of these pair-wise heteromeric subtypes, $\alpha 4 \beta 2$ is the most abundant and widely distributed in mammalian brain, whereas the $\alpha 3 \beta 4$ is the predominant nAChR subtype in the autonomic ganglia, adrenal medulla, and in subsets of nerve cells in the medial habenula, nucleus interpeduncularis, dorsal medulla, pineal gland and retina. Interestingly, in situ hybridisation studies have revealed a more abundant expression of $\alpha 2$ mRNA in primate brain than in rodents (Han et al., 2000). This suggests that $\alpha 2$-containing nAChRs may be more abundant in primate than in rodent brain, a conclusion which is supported by radioligand binding studies (Han et al., 2003). In agreement with data obtained from studies with recombinant nAChRs (as was discussed earlier), there is now extensive evidence to indicate that native neuronal nAChRs can contain more than two types of subunit. For example, amongst $\alpha 4 \beta 2^{*}$ nAChRs (a subtype which is very widely distributed within the brain), approximately $20 \%$ of these receptors also contain the $\alpha 5$ subunit (Brown et al., 2007).

In some brain areas, minor nAChR subtypes such as $\alpha 6 \beta 3^{*}$ (Champtiaux et al., 2002; Cui et al., 2003) or $\alpha 3^{*}$ (Whiteaker et al., 2002) have been detected but appear to be restricted to localised areas of the brain (reviewed in Picciotto et al., 2001; Drago et al., 2003; Gotti et al., 2006b). Such receptor subtypes do, however, constitute a high proportion of nAChRs which are expressed within these localised brain areas (Zoli et al., 2002; Moretti et al., 2004; Gotti et al., 2005b; Marritt et al., 2005). Within rodent meso-striatal (midbrain and striatum) pathway and visual (retina, superior colliculus and lateral geniculate nucleus) pathway, the $\alpha 6$ and $\beta 3$ subunits are present in two major subtypes $(\alpha 4 \alpha 6 \beta 2 \beta 3$ and $\alpha 6 \beta 2 \beta 3$ ), with the former representing $40-60 \%$ of all $\alpha 6^{*}$ receptors. These two $\alpha 6^{*}$ subtypes have different affinities and sensitivities for the antagonist $\alpha$-conotoxin MII (Zoli et al., 2002). Indeed, studies of wild-type and knock-out mice have shown that the $\alpha 4 \alpha 6 \beta 2 \beta 3$ subtype has both $\alpha 4 \beta 2$ and $\alpha 6 \beta 2$ interfaces within the same receptor molecule, each with different affinities for $\alpha$-conotoxin MII (Champtiaux et al., 2003; Salminen et al., 2007). The $\beta 3$ subunit in this nAChR subtype is not directly involved in the formation of the ligand binding site and is thought to be located in a position equivalent to that of the $\beta 1$ subunit in muscle nAChRs (Gotti et al., 2005a; Drenan et al., 2008).

Striatal $\alpha 6^{*}$ nAChRs, which have high affinity for $\alpha$-conotoxin MII, are conserved across vertebrate species (being present in rodents, monkeys and humans), although with slight differences in subunit composition and subtypes ratios (Quik et al., 2005; Gotti et al., 2006a; Bordia et al., 2007). Retinal $\alpha 6^{*}$ receptors are almost exclusively associated with $\beta 2$ subunit in mammalian subtypes (Keyser et al., 2000; Moretti et al., 2004; Marritt et al., 2005), whereas in adult chick retina $\alpha 6^{*}$ receptors are almost exclusively associated with the $\beta 4$ subunit (Vailati et al., 1999).

Expression of $\alpha 3$-containing receptors within the brain is limited (Whiteaker et al., 2002), but $\alpha 3$ subunits are present as 


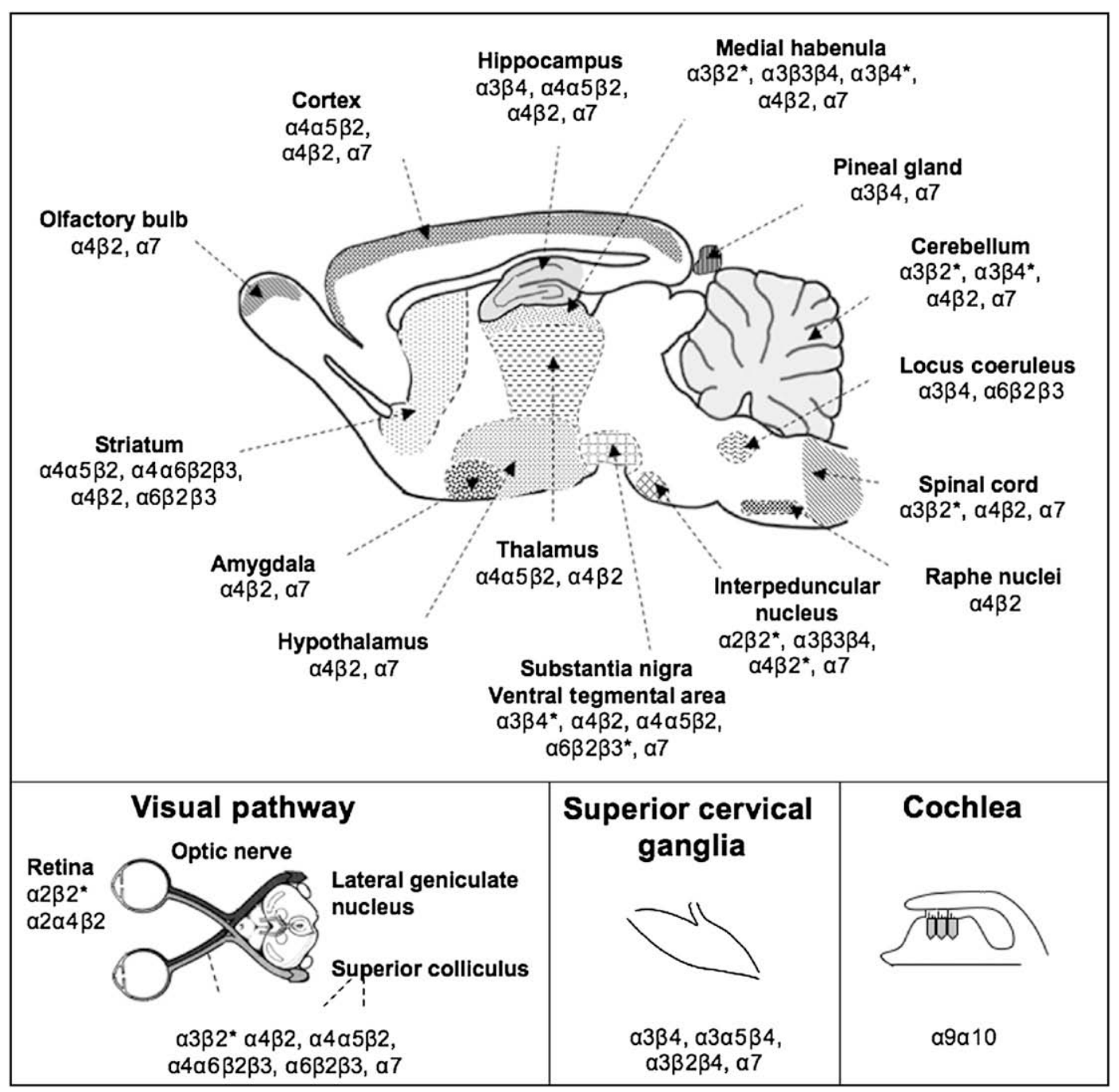

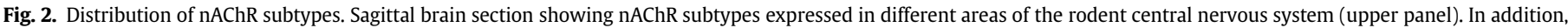

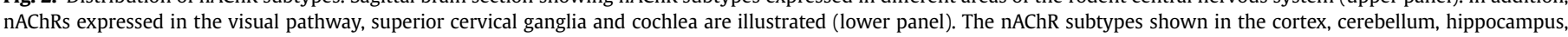

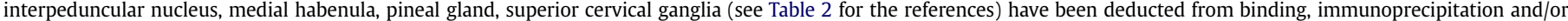

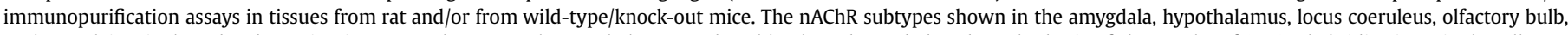

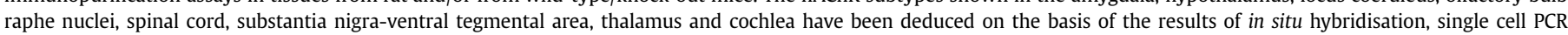

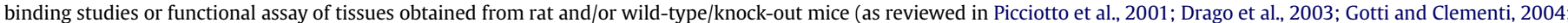
Jensen et al., 2005).

$\alpha 3 \beta 2^{*}\left(\alpha 3 \alpha 5 \beta 2^{*}\right.$ and $\alpha 3 \beta 2 \beta 3^{*}$ ) subtypes expressed in the visual pathway (Moretti et al., 2004; Gotti et al., 2005b; Marritt et al., 2005). The $\alpha 3 \beta 4$ subtype is expressed in the pineal gland (Hernandez et al., 2004), cerebellum and retina (Marritt et al., 2005; Turner and Kellar, 2005), whereas $\alpha 3 \beta 4^{*}$ subtypes are present in the cerebellum and retina (as $\alpha 3 \beta 2 \beta 4^{*}$ and $\alpha 3 \alpha 5 \beta 4^{*}$ ) (Moretti et al., 2004; Marritt et al., 2005; Turner and Kellar, 2005) and in the habenulo-interpeduncular pathway (as $\alpha 3 \beta 3 \beta 4$ ) (Gotti et al., $2006 \mathrm{~b})$. As mentioned above, $\alpha 3 \beta 4^{*}$ receptors, either with the subunit composition $\alpha 3 \beta 4$, or associated with the $\alpha 5$ and/or $\beta 2$ subunits, are the major heteromeric subtypes expressed in autonomic and sensory ganglia (Vernallis et al., 1993; Conroy and Berg, 1995; Mao et al., 2006).

The expression of $\alpha 2^{*}$-containing receptors is very limited in rodents, being restricted primarily to the retina and interpeduncular nucleus (Drago et al., 2003), but is more widespread in primates, where the $\alpha 2$ subunit has been detected (in the $\alpha 2 \alpha 5 \beta 2$ subtype) in the monkey (Quik et al., 2005) and human cortex (Gotti et al., 2006a). An $\alpha 2 \alpha 4 \beta 2$ subtype is expressed at high level in the chick optic lobe and is strongly developmentally regulated (Balestra et al., 2000).
Binding studies with $\alpha$-bungarotoxin have enabled the localization and purification of the $\alpha 7$-containing receptors from the brain of various vertebrate species, confirming that these receptors are homopentameric complexes in rat (Drisdel and Green, 2000). In avian species there is evidence that $\alpha 7$ can co-assemble the $\alpha 8$ subunit (Gotti et al., 1997; Lindstrom, 2000). Note, $\alpha 8$-containing receptors have been identified only in the chick nervous system, where they form both homomeric and heteromeric $\alpha 7 \alpha 8$ receptors (Anand et al., 1993; Keyser et al., 1993; Gotti et al., 1997). As was mentioned earlier, there is evidence that the $\alpha 7$ subunit can form functional heteromeric nAChRs in heterologous expression systems when co-assembled with the $\beta 2$ subunit (Khiroug et al., 2002) and there are some initial reports from studies in rat brain which indicate that similar $\alpha 7$-containing heteromeric nAChRs may exist in vivo (Liu et al., 2007). Interestingly, an $\alpha 7$ gene incorporating a unique 87 -base pair cassette exon has recently been identified and immunolocalisation studies suggest that this subtype may constitute a distinct subset of $\alpha 7$ receptors (Severance et al., 2004).

The $\alpha 9$ and $\alpha 10$ subunits are expressed in cochlea hair cells (Elgoyhen et al., 1994, 2001), where they have a role in auditory processing, and are probably co-assembled into heteromeric $\alpha 9 \alpha 10$ 
nAChRs (Elgoyhen et al., 2001; Katz et al., 2004; Vetter et al., 2007). There is also evidence that $\alpha 9 \alpha 10$ nAChRs are involved in processing of inflammatory pain, a finding which may be related to evidence for the expression of this receptor subtype in tissues such as dorsal root ganglia and lymphocytes (Vincler et al., 2006). In addition, there is evidence that $\alpha 7 \mathrm{nAChRs}$ play an important role in inflammatory responses (Wang et al., 2003; Ulloa, 2005). Indeed, there is increasing evidence that several 'neuronal' nAChR subunits are expressed in non-excitable cells (as has been reviewed by Sharma and Vijayaraghavan (2002), Grando (2008) and Wessler and Kirkpatrick (2008)). There is evidence, for example, of nAChR expression in epithelial cells (Summers et al., 2003), microvascular endothelial cells (Saeed et al., 2005), lung fibroblasts (Roman et al., 2004), macrophages (Matsunaga et al., 2001), T lymphocytes (Kawashima and Fujii, 2000) and B lymphocytes (Skok et al., 2003).

In general, the distribution of nAChR subtypes appears to be relatively conserved amongst different vertebrate species, although some differences are apparent. For example, as was discussed earlier, $\alpha 2$ subunit mRNA is more widely distributed in primate brain than it is in rodents, suggesting that $\alpha 2 \beta 2^{*}$ nAChRs may be more abundant subtype in primates (Han et al., 2000). A potentially powerful approach to identifying species-specific differences in the distribution of nAChR subtypes is immunolocalization. Unfortunately, however, difficulties associated with non-specific binding of some currently available antibodies have restricted the extent to which such techniques have been able to provide this information (Jones and Wonnacott, 2005; Moser et al., 2007).

\section{Rules governing $\mathrm{nAChR}$ assembly and subunit stoichiometry}

Functional studies have shown that heteromeric neuronal receptors consisting of a simple pair-wise $\alpha+\beta$ subunit combination are capable of generating functional nAChRs, but studies of native subtypes have shown that more complex receptors (with up to four different subunits) are present in vivo. Understanding such diversity is important since the presence or absence of particular subunits can influence the biophysical, pharmacological and functional properties as well as receptor assembly and/or trafficking.

The stoichiometry and subunit composition of neuronal nAChRs may depend critically on the transcriptional or translational regulation of subunit expression. A conclusion which is supported by comparing the results obtained in heterologous systems and native tissue. It has been shown, for example, that the $\alpha 4 \beta 2 \beta 3$ and $\alpha 4 \alpha 5 \beta 2$ subtypes are formed efficiently in heterologous expression systems (Kuryatov et al., 2008) whereas the former has never been determined in vivo and the latter present only in limited amount. It is also possible that observations such as this may be explained by some subunits exerting a dominant-negative effect on assembly, as has been proposed for the $\beta 3$ subunit (Broadbent et al., 2006).

The $\alpha 4, \alpha 5, \alpha 6, \beta 2$, and $\beta 3$ subunits are all expressed in mesostriatal dopaminergic cells (Klink et al., 2001), but only the $\alpha 4 \alpha 5 \beta 2$, $\alpha 4 \alpha 6 \beta 2 \beta 3, \alpha 4 \beta 2, \alpha 6 \beta 2$ and $\alpha 6 \beta 2 \beta 3$ subtypes have been biochemically and functionally identified (Zoli et al., 2002; Salminen et al., $2004,2007)$. The apparent absence of, for example, the $\alpha 4 \beta 2 \beta 3$ and $\alpha 5 \alpha 6 \beta 2$ subtypes in vivo may be due to the limited amount of the $\beta 3$ subunit, the greater propensity of the $\beta 3$ subunit to assemble with $\alpha 6$ than $\alpha 4$ (and of $\alpha 5$ to assemble with $\alpha 4$ ). A greater propensity of $\beta 3$ to assemble with $\alpha 6$ is also suggested by recent findings with $\beta 3$ knock-out mice in which $\alpha 6^{*}$ receptor expression was decreased in the dopaminergic cell bodies in the midbrain and more markedly in their terminal field in the striatum (Gotti et al., 2005a). This decrease suggests that the $\beta 3$ subunit is important for the formation of the majority of $\alpha 6 \beta 2^{*}$ or $\alpha 4 \alpha 6 \beta 2^{*}$ receptors and that its loss causes defects in nAChR assembly, degradation and/or trafficking.
As discussed above, studies of dopaminergic cells within striatum suggest that there may be as many as five different $\mathrm{nAChR}$ subtypes ( $\alpha 4 \alpha 5 \beta 2, \alpha 4 \alpha 6 \beta 2 \beta 3, \alpha 4 \beta 2, \alpha 6 \beta 2$ and $\alpha 6 \beta 2 \beta 3$ ) expressed in a single cell. It is unclear what the advantage might be (if any) of such nAChR diversity. These different subtypes may, perhaps, allow very fine control of dopamine release, or their presence in different nerve terminals or cellular subdomains may favour their association with other receptors or ion channels that modulate the release of dopamine (Quarta et al., 2007).

An additional level of complexity in studying the function of heteromeric nAChRs is the recent finding that both subunit composition and stoichiometry can generate subtypes with a distinct physiology and pharmacology (Zwart and Vijverberg, 1998; Nelson et al., 2003; Moroni et al., 2006; Tapia et al., 2007). Recent studies have shown that cortical and thalamic nAChRs in heterozygous $\left(\alpha 4^{+/-}\right.$and $\left.\beta 2^{+-}\right)$mice have different relative expressions of $\alpha 4$ and $\beta 2$ subunits, and that this correlates with differences observed in the functional properties of native nAChRs (Gotti et al., 2008), a finding which supports the conclusion that $\alpha 4 \beta 2 \mathrm{nAChRs}$ with different stoichiometries are expressed in native tissue.

\section{Conclusion}

Despite the considerable diversity of receptor subtypes within the family of nAChRs, a picture is now emerging of the extent of this diversity and of the influence of subunit composition upon physiological and pharmacological properties. Important goals for the future will be to understand in greater detail the rules governing receptor assembly and the roles played by distinct nAChR subtypes in cellular signalling and in disease.

\section{Acknowledgements}

We are grateful to Dr. Annalisa Gaimarri for the help in the preparation of Fig. 2. Work in the lab of NSM is supported by grants from the Biotechnology and Biological Sciences Research Council, the Medical Research Council and the Wellcome Trust. Work in the lab of CG is supported by research grant Fondazione Cariplo grant number 2006/0779/109251 and by FP7-Health-2007A grant number 202088-NeuroCypres from the EC. We apologize to any authors whose original contributions have not been cited owing to space restrictions.

\section{References}

Abramson, S.N., Taylor, P., 1990. Identification of nicotinic receptor ACh-binding subunits. Trends Neurosci. 13, 92.

Anand, R., Conroy, W.G., Schoepfer, R., Whiting, P., Lindstrom, J., 1991. Neuronal nicotinic acetylcholine receptors expressed in Xenopus oocytes have a pentameric quaternary structure. J. Biol. Chem. 266, 11192-11198.

Anand, R., Peng, X., Ballesta, J.J., Lindstrom, J., 1993. Pharmacological characterization of $\alpha$-bungarotoxin-sensitive acetylcholine receptors immunoisolated from chick retina: contrasting properties of $\alpha 7$ and $\alpha 8$ subunit-containing subtypes. Mol. Pharmacol. 44, 1046-1050.

Arias, H.R., 1997. Topology of ligand binding sites on the nicotinic acetylcholine receptor. Brain Res. Rev. 25, 133-191.

Baker, E.R., Zwart, R., Sher, E., Millar, N.S., 2004. Pharmacological properties of $\alpha 9 \alpha 10$ nicotinic acetylcholine receptors revealed by heterologous expression of subunit chimeras. Mol. Pharmacol. 65, 453-460.

Balestra, B., Vailati, S., Moretti, M., Hanke, W., Clementi, F., Gotti, C., 2000. Chick optic lobe contains a developmentally regulated $\alpha 2 \alpha 5 \beta 2$ nicotinic receptor subtype. Mol. Pharmacol. 58, 300-311.

Barabino, B., Vailati, S., Moretti, M., McIntosh, J.M., Longhi, R., Clementi, F., Gotti, C., 2001. An $\alpha 4 \beta 4$ nicotinic receptor subtype is present in chick retina: identification, characterization and pharmacological comparison with the transfected $\alpha 4 \beta 4$ and $\alpha 6 \beta 4$ subtypes. Mol. Pharmacol. 59, 1410-1417.

Bertrand, D., Changeux, J.P., 1995. Nicotinic receptor: an allosteric protein specialized for intercellular communication. Semin. Neurosci. 7, 75-90.

Bocquet, N., Prado de Carvalho, L., Cartaud, J., Neyton, J., Le Poupon, C., Taly, A. Grutter, T., Changeux, J.-P., Corringer, P.-J., 2007. A prokaryotic proton-gated ion channel from the nicotinic acetylcholine receptor family. Nature 445, 116-119. 
Boorman, J.P.B., Groot-Kormelink, P.J., Sivilotti, L.G., 2000. Stoichiometry of human recombinant neuronal nicotinic receptors containing the $\beta 3$ subunit expressed in Xenopus oocytes. J. Physiol. 529, 565-577.

Bordia, T., Grady, S.R., McIntosh, J.M., Quik, M., 2007. Nigrostriatal damage preferentially decreases a subpopulation of $\alpha 6 \beta 2^{*}$ nAChRs in mouse, monkey, and Parkinson's disease striatum. Mol. Pharmacol. 72, 52-61.

Boulter, J., Connolly, J., Deneris, E., Goldman, D., Heinemann, S., Patrick, J., 1987. Functional expression of two neuronal nicotinic acetylcholine receptors from cDNA clones identifies a gene family. Proc. Natl. Acad. Sci. USA 84, 7763-7767.

Boulter, J., O'Shea-Greenfield, A., Duvoisin, R.M., Connolly, J.G., Wada, E., Jensen, A., Gardner, P.D., Ballivet, M., Deneris, E.S., McKinnon, D., Heinemann, S., Patrick, J., 1990. $\alpha 3, \alpha 5$, and $\beta 4$ : three members of the rat neuronal nicotinic acetylcholine receptor-related gene family form a gene cluster. J. Biol. Chem. 265, 4472-4482.

Brejc, K., van Dijk, W.J., Klaassen, R.V., Schuurmans, M., van der Oost, J., Smit, A.B., Sixma, T.K., 2001. Crystal structure of an ACh-binding protein reveals the ligand-binding domain of nicotinic receptors. Nature 411, 269-276.

Broadbent, S., Groot-Kormelink, P.J., Krashia, P.A., Harkness, P.C., Millar, N.S., Beato, M., Sivilotti, L.G., 2006. Incorporation of the $\beta 3$ subunit has a dominantnegative effect on the function of recombinant central-type neuronal nicotinic receptors. Mol. Pharmacol. 70, 1350-1356.

Brown, R.W.B., Collins, A.C., Lindstrom, J.M., Whiteaker, P., 2007. Nicotinic $\alpha 5$ subunit deletion reduces high-affinity agonist activation without altering nicotinic receptor numbers. J. Neurochem. 103, 204-215.

Castillo, M., Mulet, J., Gutiérrez, L.M., Ortiz, J.A., Castelán, F., Gerber, S., Sala, S., Sala, F., Criado, M., 2005. Dual role of the RIC-3 protein in trafficking of serotonin and nicotinic acetylcholine receptors. J. Biol. Chem. 280, 27062-27068.

Champtiaux, N., Changeux, J.P., 2002. Knock-out and knock-in mice to investigate the role of nicotinic receptors in the central nervous system. Curr. Drug Targets CNS Neurol. Disord. 1, 319-330.

Champtiaux, N., Han, Z.-Y., Bessis, A., Rossi, F.M., Zoli, M., Marubio, L., McIntosh, J.M., Changeux, J.-P., 2002. Distribution and pharmacology of $\alpha 6$-containing nicotinic acetylcholine receptors analyzed with mutant mice. J. Neurosci. 22, 1208-1217.

Champtiaux, N., Gotti, C., Cordero-Erausquin, M., David, D.J., Przybylski, C., Léna, C., Clementi, F., Moretti, M., Rossi, F.M., Le Novère, N., McIntosh, J.M., Gardier, A.M. Changeux, J.P., 2003. Subunit composition of functional nicotinic receptors in dopaminergic neurons investigated with knock-out mice. J. Neurosci. 23, 7820-7829.

Changeux, J.-P., Edelstein, S.J., 2005. Nicotinic Acetylcholine Receptors. Odile Jacob, New York.

Charnet, P., Labarca, C., Lester, H.A., 1992. Structure of the $\gamma$-less nicotinic acetylcholine receptor: learning from omission. Mol. Pharmacol. 41, 708-717.

Chen, D., Patrick, J.W., 1997. The $\alpha$-bungarotoxin-binding nicotinic acetylcholine receptor from rat brain contains only the $\alpha 7$ subunit. J. Biol. Chem. 272, 24024-24029.

Conroy, W.G., Berg, D.K., 1995. Neurons can maintain multiple classes of nicotinic acetylcholine receptors distinguished by different subunit compositions. J. Biol. Chem. 270, 4424-4431.

Conroy, W.G., Berg, D.K., 1998. Nicotinic receptor subtypes in the developing chick brain: appearance of a species containing the $\alpha 4, \beta 2$ and $\alpha 5$ gene products. Mol. Pharmacol. 53, 392-401.

Cooper, E., Couturier, S., Ballivet, M., 1991. Pentameric structure and subunit stoichiometry of a neuronal nicotinic acetylcholine receptor. Nature 350, 235-238.

Cooper, S.T., Harkness, P.C., Baker, E.R., Millar, N.S., 1999. Upregulation of cell-surface $\alpha 4 \beta 2$ neuronal nicotinic receptors by lower temperature and expression of chimeric subunits. J. Biol. Chem. 274, 27145-27152.

Cooper, S.T., Millar, N.S., 1997. Host cell-specific folding and assembly of the neuronal nicotinic acetylcholine receptor $\alpha 7$ subunit. J. Neurochem. 68, 2140-2151.

Cooper, S.T., Millar, N.S., 1998. Host cell-specific folding of the neuronal nicotinic receptor $\alpha 8$ subunit. J. Neurochem. 70, 2585-2593.

Corringer, P.-J., Galzi, J.-L., Eliselé, J.-L., Bertrand, S., Changeux, J.-P., Bertrand, D., 1995. Identification of a new component of the agonist binding site of the nicotinic $\alpha 7$ homooligomeric receptor. J. Biol. Chem. 270, 11749-11752.

Corringer, P.-J., Le Novère, N., Changeux, J.-P., 2000. Nicotinic receptors at the amino acid level. Ann. Rev. Pharmacol. Toxicol. 40, 431-458.

Couturier, S., Bertrand, D., Matter, J.M., Hernandez, M.C., Bertrand, S., Millar, N., Valera, S., Barkas, T., Ballivet, M., 1990. A neuronal nicotinic acetylcholine receptor subunit $(\alpha 7)$ is developmentally regulated and forms a homo-oligomeric channel blocked by $\alpha$-BTX. Neuron $5,847-856$.

Cox, B.C., Marritt, A.M., Perry, D.C., Kellar, K.J., 2008. Transport of multiple nicotinic acetylcholine receptors in the rat optic nerve: high densities of receptors containing $\alpha 6$ and $\beta 3$ subunits. J. Neurochem. 105, 1924-1938.

Crabtree, G., Ramirez-Latorre, J., Role, L.W., 1997. Assembly and $\mathrm{Ca}^{2+}$ regulation of neuronal nicotinic receptors including the $\alpha 7$ and $\alpha 5$ subunits. Soc. Neurosci. Abstr. 23, 391.

Cui, C., Booker, T.K., Allen, R.S., Grady, S.R., Whiteaker, P., Marks, M.J., Salminen, O., Tritto, T., Butt, C.M., Allen, W.R., Stitzel, J.A., McIntosh, J.M., Boulter, J. Collins, A.C., Heineman, S.F., 2003. The $\beta 3$ nicotinic receptor subunit: a component of $\alpha$-conotoxin MII-binding nicotinic acetylcholine receptors that modulate dopamine release and related behaviors. J. Neurosci. 23, 11045-11053.

Del Signore, A., Gotti, C., De Stefano, M.E., Moretti, M., Paggi, P., 2002. Dystrophin stabilizes $\alpha 3$ - but not $\alpha 7$-containing nicotinic acetylcholine receptor subtypes at the postsynaptic apparatus in the mouse superior cervical ganglion. Neurobiol. Dis. 10, 54-66.
Dellisanti, C.D., Yao, Y., Stroud, J.C., Wang, Z.-Z., Chen, L., 2007. Crystal structure of the extracellular domain of $\mathrm{nAChR} \alpha 1$ bound to $\alpha$-bungarotoxin at $1.94 \AA$ resolution. Nat. Neurosci. 10, 953-962.

Drago, J., McColl, C.D., Horne, M.K., Finkelstein, D.I., Ross, S.A., 2003. Neuronal nicotinic receptors: insights gained from gene knockout and knockin mutant mice. Cell. Mol. Life Sci. 60, 1267-1280.

Drenan, R.M., Nashmi, R., Imoukhuede, P., Just, H., McKinney, S., Lester, H.A., 2008 Subcellular trafficking, pentameric assembly and subunit stoichiometry of neuronal nicotinic acetylcholine receptors containing fluorescently labeled $\alpha 6$ and $\beta 3$ subunits. Mol. Pharmacol. 73, 27-41.

Drisdel, R.C., Green, W.N., 2000. Neuronal $\alpha$-bungarotoxin receptors are $\alpha 7$ subunit homomers. J. Neurosci. 20, 133-139.

Duvoisin, R.M., Deneris, E.S., Patrick, J., Heinemann, S., 1989. The functional diversity of the neuronal nicotinic acetylcholine receptors is increased by a novel subunit: $\beta 4$. Neuron 3, 487-496.

Elgoyhen, A.B., Johnson, D.S., Boulter, J., Vetter, D.E., Heinemann, S., 1994. $\alpha 9$ : an acetylcholine receptor with novel pharmacological properties expressed in rat cochlear hair cells. Cell 18, 705-715.

Elgoyhen, A.B., Vetter, D.E., Katz, E., Rothlin, C.V., Heineman, S.F., Boulter, J., 2001 «10: a determinant of nicotinic cholinergic receptor function in mammalian vestibular and cochlear mechanosensory hair cells. Proc. Natl. Acad. Sci. U.S.A 98, 3501-3506.

Ericksen, S.S., Boileau, A.J., 2007. Tandem couture: Cys-loop receptor concatamer insights and caveats. Mol. Neurobiol. 35, 113-128.

Fucile, S., Barabino, B., Palma, E., Grassi, F., Limatola, C., Mileo, A.M., Alemà, S., Ballivet, M., Eusebi, F., 1997. $\alpha 5$ subunit forms functional $\alpha 3 \beta 4 \alpha 5$ nAChRs in transfected human cells. Neuroreport 8, 2433-2436.

Fucile, S., Matter, J.-M., Erkman, L., Ragozzino, D., Barabino, B., Grassi, F., Alemà, S. Ballivet, M., Eusebi, F., 1998. The neuronal $\alpha 6$ subunit forms functional heteromeric acetylcholine receptors in human transfected cells. Eur. J. Neurosci. 10, $172-178$.

Gerzanich, V., Anand, R., Lindstrom, J., 1994. Homomers of $\alpha 8$ and $\alpha 7$ subunits of nicotinic receptors exhibit similar channels but contrasting binding site properties. Mol. Pharmacol. 45, 212-220.

Gerzanich, V., Kuryatov, A., Anand, R., Lindstrom, J., 1997. “Orphan” $\alpha 6$ nicotinic AChR subunit can form a functional heteromeric acetylcholine receptor. Mol. Pharmacol. 51, 320-327.

Gerzanich, V., Wang, F., Kuryatov, A., Lindstrom, J., 1998. $\alpha 5$ subunit alters desensitization, pharmacology, $\mathrm{Ca}^{++}$permeability and $\mathrm{Ca}^{++}$modulation of human neuronal $\alpha 3$ nicotinic receptors. J. Pharm. Exp. Ther. 286, 311-320.

Girod, R., Crabtree, G., Ernstrom, G., Ramirez-Latorre, J., McGehee, D., Turner, J. Role, L.W., 1999. Heteromeric complexes of $\alpha 5$ and/or $\alpha 7$ subunits: effects of calcium and potential role in nictine-induced presynaptic facilitation. Ann. N.Y Acad. Sci. 868, 578-590.

Gotti, C., Clementi, F., 2004. Neuronal nicotinic receptors: from structure to pathology. Prog. Neurobiol. 74, 363-396.

Gotti, C., Hanke, W., Maury, K., Moretti, M., Ballivet, M., Clementi, F., Bertrand, D. 1994. Pharmacology and biophysical properties of $\alpha 7$ and $\alpha 7-\alpha 8 \alpha$-bungarotoxin receptor subtypes immunopurified from the chick optic lobe. Eur. J. Neurosci. 6, 1281-1291.

Gotti, C., Briscini, L., Verderio, C., Oortgiesen, M., Balestra, B., Clementi, F., 1995 Native nicotinic acetylcholine receptors in human Imr32 neuroblastoma cells: functional, immunological and pharmacological properties. Eur. J. Neurosci. 7 2083-2093.

Gotti, C., Moretti, M., Maggi, R., Longhi, R., Hanke, W., Klinke, N., Clementi, F., 1997 $\alpha 7$ and $\alpha 8$ nicotinic receptor subtypes immunoprecipitated from chick retina have different immunological, pharmacological and functional properties. Eur. J Neurosci. 9, 1201-1211.

Gotti, C., Moretti, M., Clementi, F., Riganti, L., McIntosh, J.M., Collins, A.C. Marks, M.J., Whiteaker, P., 2005a. Expression of nigrostriatal $\alpha 6$-containing nicotinic acetylcholine receptors is selectively reduced, but not eliminated, by $\beta 3$ subunit gene deletion. Mol. Pharmacol. 67, 2007-2015.

Gotti, C., Moretti, M., Zanardi, A., Gaimarri, A., Champtiaux, N., Changeux, J.-P. Whiteaker, P., Marks, M.J., Clementi, F., Zoli, M., 2005b. Heterogeneity and selective targeting of neuronal nicotinic acetylcholine receptor (nAChR) subtypes expressed on retinal afferents of the superior colliculus and latera geniculate nucleus: identification of a new native nAChR subtype $\alpha 3 \beta 2(\alpha 5$ or $\beta 3$ ) enriched in retinocollicular afferents. Mol. Pharmacol. 68, 1162-1171.

Gotti, C., Moretti, M., Bohr, I., Ziabreva, I., Vailati, S., Longhi, R., Riganti, L Gaimarri, A., McKeith, I.G., Perry, R.H., Aarsland, D., Larsen, J.P., Sher, E. Beattie, R., Clementi, F., Court, J.A., 2006a. Selective nicotinic acetylcholine receptor subunit deficits identified in Alzheimer's disease, Parkinson's disease and dementia with Lewy bodies by immunoprecipitation. Neurobiol. Dis. 23 481-489.

Gotti, C., Zoli, M., Clementi, F., 2006b. Brain nicotinic acetylcholine receptors: native subtypes and their relevance. Trends Pharmacol. Sci. 27, 482-491.

Gotti, C., Moretti, M., Meinerz, N., Clementi, F., Gaimarri, A., Collins, A.C., Marks, M.J., 2008. Partial deletion of the nicotinic cholinergic receptor $\alpha 4$ or $\beta 2$ subunit genes changes the acetylcholine sensitivity of receptor mediated $86 \mathrm{Rb}^{+}$efflux in cortex and thalamus and alters relative expression of $\alpha 4$ and $\beta 2$ subunits. Mol. Pharmacol. 73, 1796-1807.

Grando, S.A., 2008. Basic and clinical aspects of non-neuronal acetylcholine: biological and clinical significance of non-canonical ligands of epithelial nicotinic acetylcholine receptors. J. Pharmacol. Sci. 106, 174-179.

Green, W.N., Millar, N.S., 1995. Ion-channel assembly. Trends Neurosci. 18, $280-287$. 
Groot-Kormelink, P.J., Luyten, W.H.M.L., Colquhoun, D., Sivilotti, L.G., 1998. A reporter mutation approach shows incorporation of the "orphan" subunit $\beta 3$ into a functional nicotinic receptor. J. Biol. Chem. 273, 15317-15320.

Groot-Kormelink, P.J., Broadbent, S., Boorman, J.P., Sivilotti, L.G., 2004. Incomplete incorporation of tandem subunits in recombinant neuronal nicotinic receptors. J. Gen. Physiol. 123, 697-708.

Groot-Kormelink, P.J., Broadbent, S., Beato, M., Sivilotti, L.G., 2006. Constraining the expression of nicotinic acetylcholine receptors by using pentameric constructs. Mol. Pharmacol. 69, 558-563.

Han, Z.-Y., Le Novère, N., Zoli, M., Hill, J.A., Champtiaux, N., Changeux, J.-P., 2000 Localization of nAChR subunit mRNAs in the brain of Macaca mulatta. Eur. J. Neurosci. 12, 3664-3674.

Han, Z.-Y., Zoli, M., Cardona, A., Bourgeois, J.-P., Changeux, J.-P., Le Novère, N., 2003. Localization of $\left[{ }^{3} \mathrm{H}\right]$ nicotine, $\left[{ }^{3} \mathrm{H}\right]$ cytisine, $\left[{ }^{3} \mathrm{H}\right]$ epibatidine, and $\left[{ }^{125} \mathrm{I}\right] \alpha$-bungarotoxin binding sites in the brain of Macaca mulatta. J. Comp. Neurol. 461, 49-60.

Harkness, P.C., Millar, N.S., 2002. Changes in conformation and subcellula distribution of $\alpha 4 \beta 2$ nicotinic acetylcholine receptors revealed by chronic nicotine treatment and expression of subunit chimeras. J. Neurosci. 22 10172-10181.

Hernandez, S.C., Vicini, S., Xiao, Y., Dávila-García, M.I., Yasuda, R.P., Wolfe, B.B. Kellar, K.J., 2004. The nicotinic receptor in the rat pineal gland is an $\alpha 3 \beta 4$ subtype. Mol. Pharmacol. 66, 978-987.

Hilf, R.J.C., Dutzler, R., 2008. X-ray structure of a prokaryotic pentameric ligandgated ion channel. Nature 452, 375-379.

Hogg, R.C., Raggenbass, M., Bertrand, D., 2003. Nicotinic acetylcholine receptors: from structure to brain function. Rev. Physiol. Biochem. Pharmacol. 147, 1-46.

Jensen, A.A., Frolund, B., Liljefors, T., Krogsgaard-Larsen, P., 2005. Neuronal nicotinic acetylcholine receptors: structural revelations, target identification, and therapeutic inspirations. J. Med. Chem. 48, 4705-4745.

Jones, I.W., Wonnacott, S., 2005. Why doesn't nicotinic ACh receptor immunoreactivity knock out? Trends Neurosci. 28, 343-345.

Jones, A.K., Davis, P., Hodgkin, J., Sattelle, D.B., 2007. The nicotinic acetylcholine receptor gene family of the nematode Caenorhabditis elegans: an update on nomenclature. Invert. Neurosci. 7, 129-131.

Kalamida, D., Poulas, K., Avramopoulou, V., Fostieri, E., Lagoumintzis, G. Lazaridis, K., Sideri, A., Zouridakis, M., Tzartos, S.J., 2007. Muscle and neuronal nicotinic acetylcholine receptors structure, function and pathogenicity. FEBS J. 274, 3799-3845.

Kassner, P.D., Berg, D.K., 1997. Differences in the fate of neuronal acetylcholine receptor protein expressed in neurons and stably transfected cells. J. Neurobiol. 33, 968-982.

Katz, E., Elgoyhen, A.B., Gómez-Casati, M.E., Knipper, M., Vetter, D.E., Fuchs, P.A. Glowatzki, E., 2004. Developmental regulation of nicotinic synapses on cochlear inner hair cells. J. Neurosci. 24, 7814-7820.

Kawashima, K., Fujii, T., 2000. Extraneuronal cholinergic system in lymphocytes. Pharmacol. Ther. 86, 29-48.

Keyser, K.T., Britto, L.R., Schoepfer, R., Whiting, P., Cooper, J., Conroy, W., Brozozowska-Prechtl, A, Karten, H.J. Lindstrom, J. 1993. Three subtypes of $\alpha$-bungarotoxin-sensitive nicotinic acetylcholine receptors are expressed in chick retina. J. Neurosci. 13, 442-454.

Keyser, K.T., MacNeil, M.A., Dmitrieva, N., Wang, F., Masland, R.H., Lindstrom, J. 2000. Amacine, ganglion, and displaced amacrine cells in the rabbit retin express nicotinic acetylcholine receptors. Vis. Neurosci. 17, 743-752.

Khiroug, S.S., Harkness, P.C., Lamb, P.W., Sudweeks, S.N., Khiroug, L., Millar, N.S. Yakel, J.L., 2002. Rat nicotinic receptor $\alpha 7$ and $\beta 2$ subunits co-assemble to form functional heteromeric nicotinic receptor channels. J. Physiol. 540, 425-434

Klink, R., de Kerchove d'Exaerde, A., Zoli, M., Changeux, J.-P., 2001. Molecular and physiological diversity of nicotinic acetylcholine receptors in the midbrain dopaminergic nuclei. J. Neurosci. 21, 1452-1463.

Kullberg, R., Owens, J.L., Camacho, P., Mandel, G., Brehm, P., 1990. Multiple conductance classes of mouse nicotinic acetylcholine receptors expressed in Xenopus oocytes. Proc. Natl. Acad. Sci. U.S.A. 87, 2067-2071.

Kuryatov, A., Olale, F., Cooper, J., Choi, C., Lindstrom, J., 2000. Human $\alpha 6$ AChR subtypes: subunit composition, assembly, and pharmacological responses. Neuropharmacology 39, 2570-2590.

Kuryatov, A., Onksen, J., Lindstrom, J., 2008. Roles of accessory subunits in $\alpha 4 \beta 2$ nicotinic receptors. Mol. Pharmacol., doi:10.1124/mol.108.046789.

Lansdell, S.J., Gee, V.J., Harkness, P.C., Doward, A.I., Baker, E.R., Gibb, A.J., Millar, N.S. 2005. RIC-3 enhances functional expression of multiple nicotinic acetylcholine receptor subtypes in mammalian cells. Mol. Pharmacol. 68, 1431-1438.

Lansdell, S.J., Collins, T., Yabe, A., Gee, V.J., Gibb, A.J., Millar, N.S., 2008. Host-cell specific effects of the nicotinic acetylcholine receptor chaperone RIC-3 revealed by a comparison of human and Drosophila RIC-3 homologues. J. Neurochem. 105, 1573-1581.

Lindstrom, J., 2000. The structures of neuronal nicotinic receptors. In: Clementi, F. Fornasari, D., Gotti, C. (Eds.), Handbook of Experimental Pharmacology. Neuronal Nicotinic Receptors, vol. 144. Springer-Verlag, Berlin, pp. 101-162.

Lindstrom, J., Schoepfer, R., Conroy, W., Whiting, P., Das, M., Saedi, M., Anand, R. 1991. The nicotinic acetylcholine receptor gene family: structure of nicotinic receptors from muscle and neurons and neuronal alpha-bungarotoxin-binding proteins. Adv. Exp. Med. Biol. 287, 255-278.

Liu, Y., Brehm, P., 1993. Expression of subunit-omitted mouse nicotinic acetylcholine receptors in Xenopus laevis oocytes. J. Physiol. 470, 349-363.

Liu, Q., Chang, Y., Zhang, J., Xue, F., Dechon, J., Lukas, R.J., Wu, J., 2007. A novel $\alpha 7 \beta 2$ nicotinic acetylcholine receptor in forebrain cholinergic neurons is highly sensitive to amyloid beta peptides. Soc. Neurosci. Abstr. 39.1/F32.
Luetje, C.W., 2004. Getting past the asterisk: the subunit composition of presynaptic nicotinic receptors that modulate striatal dopamine release. Mol. Pharmacol. 65, 1333-1335.

Luetje, C.W., Patrick, J., 1991. Both $\alpha$ - and $\beta$-subunits contribute to the agonist sensitivity of neuronal nicotinic acetylcholine receptors. J. Neurosci. 11, 837845.

Lukas, R.J., Changeux, J.-P., Le Novère, N., Albuquerque, E.X., Balfour, D.J.K., Berg, D.K., Bertrand, D., Chiappinelli, A.A., Clarke, P.B.S., Collins, A.C., Dani, J.A., Grady, S.R., Kellar, K.J., Lindstrom, J.M., Marks, M.J., Quik, M., Taylor, P.W., Wonnacott, S., 1999. International union of pharmacology. XX. Current status of the nomenclature for nicotinic acetylcholine receptors and their subunits. Pharmacol. Rev. 51, 397-401.

Mao, D., Yasuda, R.P., Fan, H., Wolfe, B.B., Kellar, K.J., 2006. Heterogeneity of nicotinic cholinergic receptors in rat superior cervical and nodose ganglia. Mol. Pharmacol. 70, 1693-1699.

Marritt, A.M. Cox, B.C., Yasuda, R.P., McIntosh, J.M., Xiao, Y., Wolfe, B.B., Kellar, K.J. 2005. Nicotinic cholinergic receptors in the rat retina: simple and mixed heteromeric subtypes. Mol. Pharmacol. 68, 1656-1668.

Marubio, L.M., del Mar Arroyo-Jimenez, M., Cordero-Erausquin, M., Léna, C., Le Novère, N., de Kerchove d'Exaerde, A., Huchet, M., Damaj, M.I., Changeux, J.P., 1999. Reduced antinociception in mice lacking neuronal nicotinic receptor subunits. Nature 398, 805-810.

Matsunaga, K., Klein, T.W., Friedman, H., Yamamoto, Y., 2001. Involvement of nicotinic acetylcholine receptors in suppression of antimicrobial activity and cytokine responses of alveolar macrophages to Legionella pneumophila infection by nicotine. J. Immunol. 167, 6518-6524.

Millar, N.S., 2003. Assembly and subunit diversity of nicotinic acetylcholine receptors. Biochem. Soc. Trans. 31, 869-874.

Millar, N.S., 2008. RIC-3: a nicotinic acetylcholine receptor chaperone. Br. J. Pharmacol. 153, S177-S183.

Millar, N.S., Denholm, I., 2007. Nicotinic acetylcholine receptors: targets for commercially important insecticides. Invert. Neurosci. 7, 53-66.

Millar, N.S., Harkness, P.C., 2008. Assembly and trafficking of nicotinic acetylcholine receptors. Mol. Memb. Biol. 25, 279-292.

Mishina, M., Takai, T., Imoto, K., Noda, M., Takahashi, T., Numa, S., Methfessel, C., Sakman, B., 1986. Molecular distinction between fetal and adult forms of muscle acetylcholine receptor. Nature 313, 364-369.

Moretti, M., Vailati, S., Zoli, M., Lippi, G., Riganti, L., Longhi, R., Viegi, A., Clementi, F., Gotti, C., 2004. Nicotinic acetylcholine receptor subtypes expressed during rat retina development and their regulation by visual experience. Mol. Pharmacol. $66,85-96$.

Moroni, M., Zwart, R., Sher, E., Cassels, B.K., Bermudez, I., 2006. $\alpha 4 \beta 2$ nicotinic receptors with high and low acetylcholine sensitivity: pharmacology, stoichiometry, and sensitivity to long-term exposure to nicotine. Mol. Pharmacol. 70, 755-768.

Moser, N., Mechawar, N., Jones, I., Gochberg-Sarver, A., Orr-Urtreger, A., Plomann, M., Salas, R., Molles, B., Marubio, L., Roth, U., Maskos, U., WinzerSerhan, U., Bourgeois, J.-P., Le Sourd, A.-M., De Biasi, M., Schröder, H., Lindstrom, J., Maelicke, A., Changeux, J.-P., Wevers, A., 2007. Evaluating the suitability of nicotinic acetylcholine receptor antibodies for standard immunodetection procedures. J. Neurochem. 102, 479-492.

Nelson, S., Shelton, G.D., Lei, S., Lindstrom, J.M., Conti-Tronconi, B.M., 1992. Epitope mapping of monoclonal antibodies to Torpedo acetylcholine receptor $\gamma$ subunits, which specifically recognize the $\varepsilon$ subunit of mammalian muscle acetylcholine receptor. J. Neuroimmunol. 36, 13-27.

Nelson, M.E., Kuryatov, A., Choi, C.H., Zhou, Y., Lindstrom, J., 2003. Alternate stoichiometries of $\alpha 4 \beta 2$ nicotinic acetylcholine receptors. Mol. Pharmacol. 63, 332341.

Neubig, R.R., Cohen, J.B., 1979. Equilibrium binding of $\left[{ }^{3} \mathrm{H}\right]$ tubocurarine and $\left[{ }^{3} \mathrm{H}\right]$ acetylcholine by Torpedo postsynaptic membranes: stoichiometry and ligand interactions. Biochemistry 18, 5464-5475.

Noda, M., Takahashi, H., Tanabe, T., Toyosato, M., Furutani, Y., Hirose, T., Asai, M. Inayama, S., Miyata, T., Numa, S., 1982. Primary structure of $\alpha$-subunit precursor of Torpedo californica acetylcholine receptor deduced from cDNA sequence. Nature 299, 793-797.

Palma, E., Maggi, L., Barabino, B., Eusebi, F., Ballivet, M., 1999. Nicotinic acetylcholine receptors assembled from the $\alpha 7$ and $\beta 3$ subunits. J. Biol. Chem. 274, 1833518340.

Papke, R.L., Boulter, J., Patrick, J., Heinemann, S., 1989. Single-channel currents of rat neuronal nicotinic acetylcholine receptors expressed in Xenopus oocytes. Neuron 3, 589-596.

Paterson, D., Nordberg, A., 2000. Neuronal nicotinic receptors in the human brain. Prog. Neurobiol. 61, 75-111.

Picciotto, M.R., Caldarone, B.J., Brunzell, D.H., Zachariou, V., Stevens, T.R., King, S.L., 2001. Neuronal nicotinic acetylcholine receptor subunit knockout mice: physiological and behavioral phenotypes and possible clinical implications. Pharmacol. Ther. 92, 755-768.

Plazas, P.L., Katz, E., Gomez-Casati, M.E., Bouzat, C., Elgoyhen, A.B., 2005. Stoichiometry of the $\alpha 9 \alpha 10$ nicotinic cholinergic receptor. J. Neurosci. 25, 1090510912.

Popot, J.-L., Changeux, J.-P., 1984. Nicotinic receptor of acetylcholine: structure of an oligomeric integral membrane protein. Physiol. Rev. 64, 1162-1239.

Quarta, D., Ciruela, F., Patkar, K., Borycz, J., Solinas, M., Lluis, C., Franco, R., Wise, R.A. Goldberg, S.R., Hope, B.T., Woods, A.S., Ferré, S., 2007. Heteromeric nicotinic acetylcholine-dopamine autoreceptor complexes modulate striatal dopamine release. Neuropsychopharmacology 32, 35-42. 
Quick, M.W., Ceballos, R.M., Kasten, M., McIntosh, J.M., Lester, R.A.J., 1999. $\alpha 3 \beta 4$ subunit-containing nicotinic receptors dominate function in rat medial habenula neurons. Neuropharmacology 38, 768-783.

Quik, M., Vailati, S., Bordia, T., Kulak, J.M., Fan, H., McIntosh, J.M., Clementi, F., Gotti, C., 2005. Subunit composition of nicotinic receptors in monkey striatum: effect of treatments with 1-methyl-4-phenyl-1,2,3,6-tetrahydropyridine or LDOPA. Mol. Pharmacol. 67, 32-41.

Ragozzino, D., Fucile, S., Giovannelli, A., Grassi, F., Mileo, A.M., Ballivet, M., Alemà, S., Eusebi, F., 1997. Functional properties of neuronal nicotinic acetylcholine receptor channels expressed in transfected human cells. Eur. J. Neurosci. 9, 480-488.

Ramirez-Latorre, J., Yu, C.R., Qu, F., Perin, F., Karlin, A., Role, L., 1996. Functional contributions of $\alpha 5$ subunit to neuronal acetylcholine receptor channels. Nature 380, 347-351.

Rangwala, F., Drisdel, R.C., Rakhilin, S., Ko, E., Atluri, P., Harkins, A.B., Fox, A.P., Salman, S.B., Green, W.N., 1997. Neuronal $\alpha$-bungarotoxin receptors differ structurally from other nicotinic acetylcholine receptors. J. Neurosci. 17, 8201-8212.

Rogers, S.W., Gahring, L.C., Papke, R.L., Heinemann, S., 1991. Identification of cultured cells expressing ligand-gated cationic channels. Protein. Exp. Purif. 2, 108-116.

Roman, J., Ritzenthaler, J.D., Gil-Acosta, A., Rivera, H.N., Roser-Page, S., 2004. Nicotine and fibronectin expression in lung fibroblasts: implications for tobaccorelated lung tissue remodeling. FASEB J. 18, 1436-1438.

Saeed, R.W., Varma, S., Peng-Nemeroff, T., Sherry, B., Balakhaneh, D., Huston, J. Tracey, K.J., Al-Abed, Y., Metz, C.N., 2005. Cholinergic stimulation blocks endothelial cell activation and leukocyte recruitment during inflammation. J. Exp. Med. 201, 1113-1123.

Salminen, O., Murphy, K.L., McIntosh, J.M., Drago, J., Marks, M.J., Collins, A.C., Grady, S.R., 2004. Subunit composition and pharmacology of two classes of striatal presynaptic nicotinic acetylcholine receptors mediating dopamine release in mice. Mol. Pharmacol. 65, 1526-1535.

Salminen, O., Drapeau, J.A., McIntosh, J.M., Collins, A.C., Marks, M.J., Grady, S.R., 2007. Pharmacology of $\alpha$-conotoxin MII-sensitive subtypes of nicotinic acetylcholine receptors isolated by breeding of null mutant mice. Mol. Pharmacol. 71, 1563-1571.

Severance, E.G., Zhang, H., Cruz, Y., Pakhlevaniants, S., Hadley, S.H., Amin, J., Wecker, L., Reed, C., Cuevas, J., 2004. The $\alpha 7$ nicotinic acetylcholine receptor subunit exists in two isoforms that contribute to functional ligand-gated ion channels. Mol. Pharmacol. 66, 420-429.

Sgard, F., Charpantier, E., Bertrand, S., Walker, N., Caput, D., Graham, D., Bertrand, D., Besnard, F., 2002. A novel human nicotinic receptor subunit, $\alpha 10$, that confers functionality to the $\alpha 9$-subunit. Mol. Pharmacol. 61, 150-159.

Sharma, G., Vijayaraghavan, S., 2002. Nicotinic receptor signalling in nonexcitable cells. J. Neurobiol. 53, 524-534.

Sine, S.M., 1993. Molecular dissection of subunit interfaces in the acetylcholine receptor: identification of residues that determine curare selectivity. Proc. Natl. Acad. Sci. U.S.A. 90, 9436-9440.

Sine, S.M., 2002. The nicotinic receptor ligand binding domain. J. Neurobiol. 53, 431-446.

Skok, M.V., Kalashnik, E.N., Koval, L.N., Tsetlin, V.I., Utkin, Y.N., Changeux, J.-P., Grailhe, R., 2003. Functional nicotinic acetylcholine receptors are expressed in B lymphocyte-derived cell lines. Mol. Pharmacol. 64, 885-889.

Smit, A.B., Syed, N.I., Schaap, D., van Minnen, J., Klumperman, J., Kits, K.S., Lodder, H. van der Schors, R.C., van Elk, R., Sorgedrager, B., Brejc, K., Sixma, T., Geraerts, W.P.M., 2001. A glial-derived acetylcholine-binding protein that modulates synaptic transmission. Nature 411, 261-268.

Sumikawa, K., Houghton, M., Smith, J.C., Bell, L., Richards, B.M., Barnard, E.A., 1982. The molecular cloning and characterisation of cDNA coding for the $\alpha$ subunit of the acetylcholine receptor. Nucl. Acids Res. 10, 5809-5822.

Summers, A.E., Whelan, C.J., Parsons, M.E., 2003. Nicotinic acetylcholine receptor subunits and receptor activity in the epithelial cell line HT29. Life Sci. 72, 20912094.

Tapia, L., Kuryatov, A., Lindstrom, J., 2007. $\mathrm{Ca}^{2+}$ permeability of the $(\alpha 4)_{3}(\beta 2)_{2}$ stoichiometry greatly exceeds that of $(\alpha 4)_{2}(\beta 2)_{3}$ human acetylcholine receptors. Mol. Pharmacol. 71, 769-776.

Tumkosit, P., Kuryatov, A., Luo, J., Lindstrom, J., 2006. $\beta 3$ subunits promote expression and nicotine-induced up-regulation of human nicotinic $\alpha 6^{*}$ nicotinic acetylcholine receptors expressed in transfected cell lines. Mol. Pharmacol. 70, 1358-1368.
Turner, J.R., Kellar, K.J., 2005. Nicotinic cholinergic receptors in the rat cerebellum: multiple heteromeric subtypes. J. Neurosci. 25, 9258-9265.

Ulloa, L., 2005. The vagus nerve and the nicotinic anti-inflammatory pathway. Nat. Rev. Drug Discov. 4, 673-684.

Unwin, N., 2005. Refined structure of the nicotinic acetylcholine receptor at $4 \AA$ resolution. J. Mol. Biol. 346, 967-989.

Vailati, S., Hanke, W., Bejan, A., Barabino, B., Longhi, R., Balestra, B., Moretti, M., Clementi, F., Gotti, C., 1999. Functional $\alpha 6$-containing nicotinic receptors are present in chick retina. Mol. Pharmacol. 56, 11-19.

Vailati, S., Moretti, M., Longhi, R., Rovati, G.E., Clementi, F., Gotti, C., 2003. Developmental expression of heteromeric nicotinic receptor subtypes in chick retina. Mol. Pharmacol. 63, 1329-1337.

Vernallis, A.B., Conroy, W.G., Berg, D.K., 1993. Neurons assemble acetylcholine receptors with as many as three kinds of subunits while maintaining subunit segregation among receptor subtypes. Neuron 10, 451-464.

Vetter, D. E. Katz, E. Maison, S.F., Taranda, J., Turcan, S., Ballestero, J Liberman, M.C Elgoyhen, A.B., Boulter, J., 2007. The $\alpha 10$ nicotinic acetylcholine receptor subunit is required for normal synaptic function and integrity of the olivocohlear system. Proc. Natl. Acad. Sci. U.S.A. 104, 20594-20599.

Vincler, M., Wittenauer, S., Parker, R., Ellison, M., Olivera, B.M., McIntosh, J.M., 2006. Molecular mechanism for analgesia involving specific $\alpha 9 \alpha 10$ nicotinic acetylcholine receptors. Proc. Natl. Acad. Sci. U.S.A. 103, 17880-17884.

Wang, F., Gerzanich, V., Wells, G.B., Anand, R., Peng, X., Keyser, K., Lindstrom, J. 1996. Assembly of human neuronal nicotinic receptor $\alpha 5$ subunit with $\alpha 3, \beta 2$, and $\beta 4$ subunits. J. Biol. Chem. 271, 17656-17665.

Wang, H., Yu, M., Ochani, M., Amella, C.A., Tanovic, M., Susaria, S., Li, J.H., Wang, H. Yang, H., Ulloa, L., Al-Abed, Y., Czura, C.J., Tracey, K.J., 2003. Nicotinic acetylcholine receptor $\alpha 7$ subunit is an essential regulator of inflammation. Nature 421, 384-388.

Weill, C.L., McNamee, M.G., Karlin, A., 1974. Affinity-labeling of purified acetylcholine receptor from Torpedo californica. Biochem. Biophys. Res. Comm. 61, 9971003.

Wessler, I., Kirkpatrick, C.J., 2008. Acetylcholine beyond neurons: the non-neurona cholinergic system in humans. Br. J. Pharmacol., doi:10.1038/bjp.2008.1185.

Whiteaker, P., Peterson, C.G., Xu, W., McIntosh, J.M., Paylor, R., Beaudet, A.L., Collins, A.C., Marks, M.J., 2002. Involvement of the $\alpha 3$ subunit in central nicotinic binding populations. J. Neurosci. 22, 2522-2529.

Whiting, P.J., Lindstrom, J.M., 1986. Purification and characterization of a nicotinic acetylcholine receptor from chick brain. Biochemistry 25, 2082-2093.

Whiting, P.J., Lindstrom, J.M., 1988. Characterization of bovine and human neuronal nicotinic acetylcholine receptors using monoclonal antibodies. J. Neurosci. 8, 3395-3404

Whiting, P., Schoepfer, R., Lindstrom, J., Priestley, T., 1991. Structural and pharmacological characterization of the major brain nicotinic acetylcholine receptor subtype stably expressed in mouse fibroblasts. Mol. Pharmacol. 40, 463-472.

Whiting, P.J., Liu, R., Morley, B.J., Lindstrom, J.M., 1987. Structurally different neuronal nicotinic acetylcholine receptor subtypes purified and characterized using monoclonal antibodies. J. Neurosci. 7, 4005-4016.

Williams, M.E., Burton, B., Urrutia, A., Shcherbatko, A., Chavez-Noriega, L.E. Cohen, C.J., Aiyar, J., 2005. Ric-3 promotes functional expression of the nicotinic acetylcholine receptor $\alpha 7$ subunit in mammalian cells. J. Biol. Chem. 280, 12571263.

Witzemann, V., Barg, B., Criado, M., Stein, E., Sakmann, B., 1989. Developmental regulation of five subunit specific mRNAs encoding acetylcholine receptor subtypes in rat muscle. FEBS Lett. 242, 419-424.

Wong, E.T., Holstad, S.G., Mennerick, S.J., Hong, S.E., Zorumski, C.F., Isenberg, K.E. 1995. Pharmacological and physiological properties of a putative ganglionic nicotinic receptor $\alpha 3 \beta 4$, expressed in transfected eucaryotic cells. Mol. Brain Res. 28, 101-109.

Zhou, Y., Nelson, M.E., Kuryatov, A., Choi, C.H., Cooper, J., Lindstrom, J., 2003. Human $\alpha 4 \beta 2$ acetylcholine receptors formed from linked subunits. J. Neurosci. 23 9004-9015.

Zoli, M., Moretti, M., Zanardi, A., McIntosh, J.M., Clementi, F., Gotti, C., 2002. Identification of the nicotinic receptor subtypes expressed on dopaminergic terminals in the rat striatum. J. Neurosci. 22, 8785-8789.

Zwart, R., Vijverberg, H.P.M., 1998. Four pharmacologically distinct subtypes of $\alpha 4 \beta 2$ nicotinic acetylcholine receptor expressed in Xenopus laevis oocytes. Mol. Pharmacol. 54, 1124-1131. 